\title{
SOIL ORGANIC MATTER FRACTIONS AND CARBON MANAGEMENT INDEX UNDER INTEGRATED CROP-LIVESTOCK SYSTEM
}

\author{
FRAÇÕES DA MATÉRIA ORGÂNICA DO SOLO E ÍNDICE DE MANEJO DE \\ CARBONO SOB SISTEMA DE INTEGRAÇÃO LAVOURA-PECUÁRIA
}

\begin{abstract}
Jeferson Tiago PIANO ${ }^{1}$; Carlos Augusto Rocha de Moraes REGO² Andressa Perini VENGEN ${ }^{3}$; Jonas Francisco EGEWARTH ${ }^{2}$; Vanessa Aline EGEWARTH ${ }^{4}$; Eloisa MATTEI ${ }^{2}$; Paulo Sérgio Rabello de OLIVEIRA; ${ }^{5}$ Juan López de HERRERA ${ }^{6}$

1. Pós-Doutorando no Programa de Pós-Graduação em Agronomia, UNIOESTE, Campus Marechal Cândido Rondon, PR, Brasil; 2. Doutorando(a) no Programa de Pós-Graduação em Agronomia, Universidade Estadual do Oeste do Paraná - UNIOESTE, Campus Marechal Cândido Rondon, PR, Brasil. cassielcarlos@hotmail.com; 3. Mestre em Agronomia, UNIOESTE, Campus Marechal Cândido Rondon, PR, Brasil; 4. Professora, Doutora, Colégio Agrícola Estadual de Toledo, CAGEFMP, Toledo, PR, Brasil; 5. Professor, Doutor, UNIOESTE, Campus Marechal Cândido Rondon, PR, Brasil; 6. Professor, Doutor, Universidad Politécnica de Madrid - UPM, Madrid - Espanha.
\end{abstract}

\begin{abstract}
The objective of this work was to evaluate the carbon content of the physical, chemical and oxidizable fractions of soil organic matter (SOM) and to calculate the carbon management index (CMI) in an area managed under an integrated crop-livestock system (ICLS) in the western region of Paraná - Brazil. The experiment was carried out at the experimental farm, belonging to the Universidade Estadual do Oeste do Paraná. Seventeen areas, which are managed in different ways, fifteen in ICLS and two areas of controls (Forest and Haymaking), using the design divided with two nested controls, with three replications were evaluated. Deformed and undisturbed soil samples were collected from all the areas to determine the total organic carbon (TOC), carbon stock, the physical, chemical and oxidizable fractions of SOM and the CMI in the layers of 0-0.05, 0.05-0.1 and 0.1-0.2 m. Little significant changes in the fractions were found for the management of the ICLS area in relation to the Forest and the area of Haymaking, although the Forest presented the best values for most of the studied fractions. It is recommended to adopt sustainable practices, such as ICLS, even though the average fractions tend to take time to match reference areas.
\end{abstract}

KEYWORDS: Carbon stock. Humic substances. Particulate carbon.

\section{INTRODUCTION}

Soil organic matter (SOM) is a sensitive indicator of soil changes due to its use and occupation (BALDOTTO et al., 2015), since the anthropic action of replacing natural ecosystems with agroecosystems for food production, often favors a decline in the organic carbon $(\mathrm{C})$ content of the soil, due to the reduction of the contribution, and losses due to erosion and changes in the rate of decomposition of organic matter (HICKMANN; COSTA, 2012). Variable additions of organic matter throughout the year are usually associated with fallow systems, such as low productivity crops, burning or removal of cultural residues, contributing to low annual deposited $\mathrm{C}$ values (PEREIRA et al., 2013).

Besides directly affecting the SOM, causing the decrease of the contribution of C (SILVA et al., 2013), management systems that provide small contributions of cultural residues are not indicated. Therefore, it is recommended the use of conservationist systems, which interfere little in the soil structure, such as the no-tillage system (HICKMANN; COSTA, 2012) or the integrated crop-livestock system (ICLS) are recommended (CASTAGNARA et al., 2015; PIANO et al., 2015). Another important aspect of the use of ICLS is that it provides $\mathrm{C}$ cycling promoted by deposition of feces and animal urine at the soil surface (BAYER et al., 2011).

In this way, it is important to maintain the vegetal residues on the soil surface and to reduce its revolving, since they contribute positively to the soil C storage (SALTON et al., 2011). Moreover, the dynamic balance between the addition of cultural residues and loss by decomposition or mineralization represents the $\mathrm{C}$ stock of soil (PEREIRA et al., 2013), although the rates of addition and the quality of vegetation $\mathrm{C}$ depend heavily on the climate, vegetation type, soil fertility (BERTNER et al., 2011), and the soil management system (BAYER et al., 2011) as soil density has a direct impact on soil C stocks.

There are several ways of studying the dynamics of SOM, among them, the granulometric 
physical fractionation (CAMBARDELLA; ELLIOTT, 1992), the oxidation fractionation (CHAN; BOWMAN; OATES, 2001), the chemical fractionation (SWIFT, 1996; BENITES; MADARI; MACHADO, 2003), and the carbon management index (CMI) (BLAIR; LEFROY; LISLE, 1995). Among these, the form used as an indicator of soil quality, more sensitive to changes in management, is the physical granulometric fractionation of soil in Particulate Organic Carbon (POC) and Organic Carbon Associated with Minerals (OCAM) (BALIN et al., 2017; FACCIN et al., 2016), because they are based on the degree of association of SOM with the soil matrix (GAZOLLA et al., 2015). Carbon is called POC when it is free or weakly associated with soil particles, or OCAM, when $\mathrm{C}$ is strongly bound to the mineral particles, forming organicmineral complexes (GAZOLLA et al., 2015).

Also, by evaluating the SOM granulometric compartments, it is possible to estimate the CMI between cultivated areas and those in equilibrium (native vegetation), increasing the number of soil organic compartment quality indicators (BLAIR; LEFROY; LISLE, 1995). In addition to the physical fraction, the oxidizable fractions of SOM assist in the interpretation of soil $\mathrm{C}$ dynamics (CHAN; BOWMAN; OATES, 2001). They are based on the oxidation levels of $\mathrm{C}$ and present four fractions ( $\mathrm{F} 1$, F2, F3, and F4). The first two are related to nutrient availability and the formation and stabilization of macroaggregates (BARRETO et al., 2011); and the last two are related to compounds of greater chemical stability and molecular weight, common in the soil humic fractions of the SOM that remain longer in the soil (CHAN; BOWMAN; OATES, 2001).

Most studies focus on TOC, however, small changes in $\mathrm{C}$ totals are difficult to detect in the short term because the natural soil variability is high (SILVA et al., 2011). The largest compartment of SOM, waters, and sediments occurs in the form of Humic Substances (HS), a heterogeneous mixture of organic compounds aggregated by weak hydrophobic interactions and by hydrogen bonds (BALDOTTO et al., 2013). The HS is fractionated as a function of its solubility at different $\mathrm{pH}$ values: Humic Acids (HA), Fulvic Acids (FA) and Humic (HUM) (ROSSI et al., 2011).

Changes, such as decreased or increased the SOM, allow calculating the level of conservation of natural ecosystems and the potential impacts on farming systems with different types of soil management (SILVA et al., 2011). Most of the SOM, in tropical environments, is formed by the HS (PARTELLI et al., 2009), which may reflect the changes that have occurred due to anthropic alterations. The characterization of these fractions presents great potential for the evaluation of soil quality (BENITES et al., 2010), through the chemical fractionation of the SOM (LOSS et al., 2010).

The use of different management systems deserves special attention because it can impact the organic matter content of the soil, that is, to influence the carbon cycle of the soil. From the above, our hypothesis is that the use of the soil with crop integration system, using annual grazing winter forages, provides increases of carbon within the physical, chemical and oxidizable fractions of SOM and to calculate the carbon management index. Therefore, this study aimed to evaluate the carbon content of the physical, chemical and oxidizable fractions of soil organic matter (SOM) and to calculate the carbon management index (CMI) in an area managed under an integrated crop-livestock system (ICLS) in the western region of Paraná Brazil.

\section{MATERIAL AND METHODS}

\section{Location of the experiment}

The experiment was conducted at the Experimental Station Professor Antônio Carlos dos Santos Pessoa, belonging to the Universidade Estadual do Oeste do Paraná (UNIOESTE), Campus Marechal Cândido Rondon - Paraná - Brazil. The altitude of the site is $400 \mathrm{~m}$, with the coordinates of $24^{\circ} 31^{\prime} 58^{\prime \prime} \mathrm{S}$ and $54^{\circ} 01^{\prime} 10^{\prime \prime} \mathrm{W}$. According to the Köppen classification, the climate of the region is the Cfa type: humid subtropical mesothermic of dry winter, with well-distributed rainfall throughout the year and hot summers (ALVARES et al., 2014). The soil of the area is classified as a Eutrophic Red Latosol, of very clayey texture (SANTOS et al., 2013a), and due to the proximity between the areas the average levels found in the layer of 0.00 to 0.10 $\mathrm{m}$ are of $681.0 \mathrm{~g} \mathrm{~kg}^{-1}$ of clay, $266.5 \mathrm{~g} \mathrm{~kg}^{-1}$ of silt and $52.5 \mathrm{~g} \mathrm{~kg}^{-1}$ of sand, and for the layer 0.10 to $0.20 \mathrm{~m}$ contents of $751.5 \mathrm{~g} \mathrm{~kg}^{-1}$ clay, $199.1 \mathrm{~g} \mathrm{~kg}^{-1}$ silt and $49.4 \mathrm{~g} \mathrm{~kg}^{-1}$ sand.

\section{Assessed management systems}

The evaluated systems comprised seventeen forms of management. In an agricultural area that had been managed for four years under ICLS (soybean in the summer and autumnal forage for grazing of milk cattle in the winter), with no-tillage in consolidation, the forage species tested were: black oats cv. BRS 139 (O 139), black oats cv. IPR 61 (O 61), white oats cv. IPR Esmeralda (OE), 
Triticale cv. IPR 111 (T) and the triticale consortium with white oats cv. IPR Esmeralda $(\mathrm{CON})$. These forages were managed with different grazing: without grazing (WG), one grazing (1G) and two grazings $(2 \mathrm{G})$. Also evaluated were an area of Forest and Haymaking that were considered as controls areas.

For the winter fodder sowing, the area was desiccated thirty days before sowing of the species, using glyphosate-salt of Isopropylamine and Cletodim, at doses of $4 \mathrm{~L} \mathrm{ha}^{-1}$ and $0.5 \mathrm{~L} \mathrm{ha}^{-1}$ of the commercial product, respectively, with flow rate of $100 \mathrm{~L} \mathrm{ha}^{-1}$. Sowing of forage species was on April 16, 2016, using continuous flow seeder directly on the soybean straw, with a spacing of $0.17 \mathrm{~m}$ between rows. Seeding rates were $60 \mathrm{~kg} \mathrm{ha}^{-1}, 140 \mathrm{~kg}$ $\mathrm{ha}^{-1}$ and $40 \pm 120 \mathrm{~kg} \mathrm{ha}^{-1}$ for oats, triticale, and consortium, respectively. The base fertilization was $25 \mathrm{~kg} \mathrm{ha}^{-1}$ of $\mathrm{N}, 38 \mathrm{~kg} \mathrm{ha}^{-1}$ of $\mathrm{P}_{2} \mathrm{O}_{5}$ and $38 \mathrm{~kg} \mathrm{ha}^{-1}$ of $\mathrm{K}_{2} \mathrm{O}$.

During the growth of the forages, cover fertilization was carried out in a Split topdressing piecemeal manner, totaling $120 \mathrm{~kg} \mathrm{ha}^{-1}$ of $\mathrm{N}$ with urea. Regarding phytosanitary treatments, during the forage cycle, there was no need to apply herbicides, insecticides or fungicides.

For grazing, animals of the Dutch breed during lactation were used, with an average weight of $600 \mathrm{~kg} \pm 50 \mathrm{~kg}$. The grazing was started when the plants reached a height between 0.25 to $0.35 \mathrm{~m}$, about 80 days after the emergency. The animals were removed when the plants had reached $0.15 \mathrm{~m}$ height, so that there were no damages to the plant apical meristem, being able to grow again to the formation of straw sufficient for the direct tillage of the soybean in succession (FONTANELI; SANTOS; FONTANELLI, 2012).

In order to implant the soybean crop, the area was previously desiccated, 20 days before sowing, using Isopropylamine + Clethodim glyphosate salt at $3.0 \mathrm{~L} \mathrm{ha}^{-1}$ and $0.40 \mathrm{~L} \mathrm{ha}^{-1}$ of the product containing $480 \mathrm{~g} \mathrm{~L}^{-1}$ and $240 \mathrm{~g} \mathrm{~L}^{-1}$ of active ingredient respectively. The sowing of soybean was carried out in no-tillage system, on October 21, 2016, using the NIDERA 5909 RR cultivar, $0.50 \mathrm{~m}$ row spacing, $4 \mathrm{~cm}$ depth and 14 seeds per linear meter. For the basic fertilization, $310 \mathrm{~kg} \mathrm{ha}^{-1}$ of the commercial formulation 02-20-18 (N, $\mathrm{P}_{2} \mathrm{O}_{5}$, and $\mathrm{K}_{2} \mathrm{O}$ ) was used. Due to the development of the crop, applications of fungicides Piraclostrobin + Fluxapiroxade at the dose of $300 \mathrm{~mL} \mathrm{ha}{ }^{-1}$, commercial product; and insecticides: Neonicotinoid + Pyrethroid and Benzoylurea, at doses of $250 \mathrm{~mL} \mathrm{ha}^{-1}$ and $300 \mathrm{~mL} \mathrm{ha}^{-1}$, commercial product, respectively, with flow rate of $100 \mathrm{~L} \mathrm{ha}^{-1}$.
The soybean harvest was performed mechanically on March 03, 2017.

The Haymaking area was being managed with the production of hay for feeding the animals from the experimental farm of the university during the last 10 years, with the cultivation of Tifton 85 grass (Cynodon spp.), with periodic fertilization of swine manure from its own university, being located $230 \mathrm{~m}$ from the ICLS. The Forest area has been maintained on permanent preservation as a fragment, which is classified as Semidecidual Seasonal Forest (VELOSO; RANGEL FILHO; LIMA, 1991), being located about 1,130 $\mathrm{m}$ from the ICLS area.

\section{Collection of soil samples and assessments}

Soil collections were carried out in March 2017 , almost a year after the sowing of forages in the agricultural area. In order to collect soil samples within the management systems, three plots were chosen at random within each area. In each plot, four samples of deformed soil with an auger Dutch type were collected and homogenized to form a composite sample in the 0-0.05 $\mathrm{m}, 0.05-0.1$ and 0.1 $0.2 \mathrm{~m}$ layers.

The determination of the TOC was carried out by wet oxidation using $0.116 \mathrm{~mol} \mathrm{~L}^{-1}$ potassium dichromate solution and concentrated sulfuric acid, with digestion block heating (YEOMANS; BREMNER, 1988). The granulometric physical fractionation of the organic matter was carried out according to the methodology proposed by Cambardella and Elliot (1992), and also the determination of the POC and OCAM.

The carbon stocks of TOC, POC and OCAM were calculated using the following equation: $\mathrm{Cst}=(\mathrm{C} \times \mathrm{SD} \times \mathrm{T}) / 10$, where: $\mathrm{Cst}$ represents the carbon stock in a given layer expressed in $\mathrm{Mg} \mathrm{ha}{ }^{-1}$; $\mathrm{C}$ represents the Carbon content in the layer $\left(\mathrm{g} \mathrm{kg}^{-1}\right)$; SD represents the Soil Density $\left(\mathrm{Mg} \mathrm{m}^{-3}\right)$, determined by the average of three points collected within each area by the volumetric ring method (DONAGEMA et al., 2011) for each depth; $\mathrm{T}$ represents the thickness of the layer under analysis, in cm (FREIXO et al., 2002).

In order to adequately compare the calculated inventories between the areas, it was necessary to make comparisons between equal masses of soil, adjusting the values of the layers used in the calculations using the method of Ellert and Bettany (1995). For corrections for the equivalent soil mass, the native Forest area was considered the reference area and calculated by the equation: Corrected depth $(\mathrm{cm})=($ MDref / MDcor) $\mathrm{x}$ DEPcor, where: MDref represents the mean 
density of the reference area $\left(\mathrm{g} \mathrm{cm}^{-3}\right)$; MDcor is the mean density of the area being corrected $\left(\mathrm{g} \mathrm{cm}^{-3}\right)$; and DEPcor is the original depth of the layer being corrected (cm), as suggested by Signor et al. (2014), with small modifications in relation to the average density instead of the weighted one.

Calculation of the Carbon Management Index (CMI) is made considering a Carbon Stock Index (CSI) that relates the content of TOC of the cultivated area under study in relation to the reference area system (native Forest). We calculate CMI by means of the equation: $\mathrm{CMI}=\mathrm{CSI} \mathrm{x}$ LABI $\mathrm{X} 100$, from the results of TOC and each granulometric fraction stocks (BLAIR; LEFROY; LISLE, 1995; CONCEIÇÃO et al., 2014). The lability (LAB) is determined by the relationship between particulate organic carbon stock (POCst) and the organic carbon stock associated with silt and clay minerals (OCAMst). The lability index (LABI) is calculated by the relation between the LAB of the cultivated area and the LAB of the reference area. Because it was a study that used two areas as control (Forest and Haymaking) for the calculations of the indices, the native Forest area was used as a total control, since it deals with the environment without anthropic action.

The oxidizable fractionation was performed by the degrees of oxidation established by Chan, Bowman and Oates (2001), which obtained four fractions with decreasing degrees of lability by the adapted method proposed by Mendonça and Matos (2017), in which the soil is oxidized by a solution of potassium dichromate $0.167 \mathrm{~mol} \mathrm{~L}^{-1}$ in acid medium in three different concentrations $\left(3,6\right.$ and $\left.9 \mathrm{~mol} \mathrm{~L}^{-1}\right)$ of $\mathrm{H}_{2} \mathrm{SO}_{4}$, giving four fractions: Very easily labile fraction (F1); Easily labile fraction (F2); Moderately labile fraction (F3); and Fraction resistant (F4). The relationship between $(\mathrm{F} 1 / \mathrm{F} 4)$ and $(\mathrm{F} 1+\mathrm{F} 2) /(\mathrm{F} 3+\mathrm{F} 4)$ was used to obtain indexes to facilitate the understanding of the dynamics between these fractions.

For the fractionation of the humic substances (HS), it was used the methodology based on the differential solubility and subsequent determination of carbon of each fraction, being: Humina (HUM), Fulvic Acid (FA) and Humic Acid (HA), established by the International Society of Humic Substances (SWIFT, 1996) and adapted by Mendonça and Matos (2017).

After determining the carbon content in HS, the following relations of interest were calculated: $\mathrm{HA} / \mathrm{AF}$ (indicates Soil Carbon Mobility) and Alkaline Extract AE/HUM (indicates the organic matter illuviation in the soil profile) to verify the humification processes of SOM (CANELLAS; SANTOS, 2005).

\section{Development and statistical analysis}

The experimental design was subdivided with two nested controls, with three replicates, totaling 51 experimental plots. The data were submitted to analysis of variance with $\mathrm{R}$ (Core Development Core Team, 2016) and the means, when obtained by $\mathrm{F}$ test $(\mathrm{P} \leq 0.05)$, were compared by the Dunnett test with Genes software (CRUZ, 2013).

\section{RESULTS AND DISCUSSION}

For the TOC contents, the Forest area presented the highest content $\left(31.98 \mathrm{~g} \mathrm{~kg}^{-1}\right)$, in the 0-0.05 $\mathrm{m}$ layer. In this layer, the other management systems presented levels that were equal to or smaller than the Haymaking area. In the other layers studied (0.05-0.10 and $0.10-0.20 \mathrm{~m})$, the TOC contents in the Forest zone were higher than all the other management systems studied (Table 1). The low TOC content found in the winter forage areas is due to the short conversion period between the conventional planting system and the ICLS (4 years). Among the factors that can affect the TOC levels, we can find soil, climate, management system, but also changes in the levels of $\mathrm{C}$ in areas converted to ICLS can be observed after 10-15 years (CARVALHO et al., 2009).

Similar results were reported by Schiavo et al. (2011) and Dortzbach et al. (2015), which verified differences in TOC levels both between treatments and depths, and found the highest levels in native vegetation areas. Higher TOC values in native vegetation areas occur due to the higher amount of vegetal residues on the soil surface, associated with the absence of anthropic action (GAZOLLA et al., 2015). The TOC content tends to decrease in depth, as observed in this work in the native vegetation, the reduction was of $28 \%$ between the superficial layer and the deepest. This result is due to the greater contributions of SOM in the superficial layers (BATISTA et al., 2013; DORTZBACH et al., 2015).

Minor TOC content in the area of ICLS and Haymaking, also show the negative impact that occurred in the soil after conversion of forest to agriculture or livestock (DORTZBACH et al., 2015). Minor TOC values are related to inadequate management or the concurrence of degraded pastures, resulting in lower nutrient cycling in these areas compared to Forest areas (SILVA et al., 2012). 
Table 1. Mean values of total organic carbon (TOC), particulate organic carbon (POC), organic carbon associated with minerals (OCAM) and total carbon stock (TOCst)

\begin{tabular}{|c|c|c|c|c|c|c|}
\hline \multirow{2}{*}{ Management } & \multicolumn{3}{|c|}{ TOC $\mathrm{g} \mathrm{kg}^{-1}$} & \multicolumn{3}{|c|}{ POC $\mathrm{g} \mathrm{kg}^{-1}$} \\
\hline & $0-0.05 \mathrm{~m}$ & $0.05-0.1 \mathrm{~m}$ & $0.1-0.2 \mathrm{~m}$ & $0-0.05 \mathrm{~m}$ & $0.05-0.1 \mathrm{~m}$ & $0.1-0.2 \mathrm{~m}$ \\
\hline O $139 \mathrm{WG}$ & 19.82 & $20.45 b$ & $17.90 \mathrm{~b}$ & $12.78 \mathrm{ab}$ & $13.30 \mathrm{ab}$ & $12.74 \mathrm{ab}$ \\
\hline EO WG & $23.23 b$ & $21.93 b$ & $19.26 \mathrm{ab}$ & $13.13 \mathrm{ab}$ & $15.65 \mathrm{ab}$ & $15.91 b$ \\
\hline O $61 \mathrm{WG}$ & 20.61 & $22.47 b$ & $19.44 \mathrm{ab}$ & $12.86 \mathrm{ab}$ & $13.14 \mathrm{ab}$ & $15.75 b$ \\
\hline T WG & $23.05 b$ & $23.47 \mathrm{ab}$ & $16.97 \mathrm{~b}$ & $11.92 \mathrm{ab}$ & $13.99 \mathrm{ab}$ & $12.50 \mathrm{ab}$ \\
\hline CON WG & 21.34 & $20.02 b$ & $19.62 \mathrm{ab}$ & $12.78 \mathrm{ab}$ & $10.90 \mathrm{ab}$ & $12.69 b$ \\
\hline O $1391 \mathrm{G}$ & 20.80 & $20.08 b$ & $18.72 b$ & $11.26 \mathrm{ab}$ & $12.41 \mathrm{ab}$ & $13.96 \mathrm{~b}$ \\
\hline EO $1 G$ & 21.20 & $20.12 b$ & $16.08 \mathrm{~b}$ & $13.66 \mathrm{ab}$ & $13.55 \mathrm{ab}$ & $13.50 \mathrm{~b}$ \\
\hline $\mathrm{O} 611 \mathrm{G}$ & 20.78 & $19.18 b$ & $17.80 \mathrm{~b}$ & $12.99 \mathrm{ab}$ & $12.95 \mathrm{ab}$ & $17.09 b$ \\
\hline $\mathrm{T} 1 \mathrm{G}$ & 21.45 & $21.52 b$ & $18.57 b$ & $14.92 \mathrm{ab}$ & 16.86 & $13.72 b$ \\
\hline CON $1 \mathrm{G}$ & 20.39 & $19.24 b$ & $16.88 b$ & $9.17 \mathrm{~b}$ & $14.13 \mathrm{ab}$ & $15.51 \mathrm{~b}$ \\
\hline O $1392 \mathrm{G}$ & $22.01 \mathrm{~b}$ & $19.54 b$ & $17.23 \mathrm{~b}$ & $14.13 \mathrm{ab}$ & $13.63 \mathrm{ab}$ & $9.55 \mathrm{ab}$ \\
\hline EO $2 \mathrm{G}$ & 20.84 & $18.69 \mathrm{~b}$ & $18.06 \mathrm{~b}$ & $14.58 \mathrm{ab}$ & $12.52 \mathrm{ab}$ & $13.11 \mathrm{~b}$ \\
\hline $\mathrm{O} 612 \mathrm{P}$ & 20.90 & $19.35 b$ & $17.87 \mathrm{~b}$ & $11.32 \mathrm{ab}$ & $13.10 \mathrm{ab}$ & $11.55 \mathrm{ab}$ \\
\hline T $2 \mathrm{G}$ & 20.78 & $22.01 \mathrm{~b}$ & $16.97 \mathrm{~b}$ & $13.28 \mathrm{ab}$ & 16.49 & $12.69 \mathrm{ab}$ \\
\hline CON $2 \mathrm{G}$ & $21.96 b$ & $20.82 b$ & $17.44 b$ & $11.55 \mathrm{ab}$ & $15.08 \mathrm{ab}$ & $12.72 \mathrm{ab}$ \\
\hline Forest & $31.98 \mathrm{a}$ & $27.12 \mathrm{a}$ & $23.15 \mathrm{a}$ & $16.78 \mathrm{a}$ & $9.27 \mathrm{a}$ & $7.13 \mathrm{a}$ \\
\hline \multirow[t]{2}{*}{ Haymaking } & $25.42 b$ & $22.54 b$ & $20.40 b$ & $9.42 \mathrm{~b}$ & $9.57 \mathrm{~b}$ & $13.41 \mathrm{~b}$ \\
\hline & \multicolumn{3}{|c|}{ OCAM g kg ${ }^{-1}$} & \multicolumn{3}{|c|}{ TOCst $\mathrm{Mg} \mathrm{ha}^{-1}$} \\
\hline O $139 \mathrm{WG}$ & 7.05 & $7.15 b$ & $5.16 \mathrm{~b}$ & 6.71 & 6.05 & 12.48 \\
\hline EO WG & $10.10 \mathrm{ab}$ & $6.27 \mathrm{~b}$ & $3.35 b$ & 6.85 & 6.65 & 13.51 \\
\hline O $61 \mathrm{WG}$ & 7.75 & $9.33 b$ & $3.70 \mathrm{~b}$ & 7.29 & 6.74 & 13.63 \\
\hline T WG & $11.12 \mathrm{ab}$ & $9.49 b$ & $4.48 b$ & 6.94 & 6.69 & 11.76 \\
\hline CON WG & $8.56 \mathrm{a}$ & $9.12 \mathrm{~b}$ & $6.93 b$ & 6.49 & 6.18 & 13.75 \\
\hline O $1391 \mathrm{G}$ & $9.54 \mathrm{ab}$ & $7.68 b$ & $4.76 b$ & 6.20 & 6.03 & 12.91 \\
\hline EO $1 \mathrm{G}$ & 7.54 & $6.58 b$ & $2.57 \mathrm{~b}$ & 6.15 & 6.04 & 10.78 \\
\hline $\mathrm{O} 611 \mathrm{G}$ & 7.80 & $6.23 b$ & $0.71 b$ & 6.72 & 5.80 & 12.82 \\
\hline $\mathrm{T} 1 \mathrm{G}$ & 6.52 & 4.66 & $4.85 b$ & 7.17 & 6.56 & 12.91 \\
\hline CON $1 G$ & $11.21 \mathrm{ab}$ & 5.11 & $1.38 \mathrm{~b}$ & 6.02 & 5.70 & 12.35 \\
\hline O $1392 \mathrm{G}$ & 7.88 & $5.91 b$ & $7.68 b$ & 7.15 & 5.84 & 11.85 \\
\hline EO $2 \mathrm{G}$ & 6.26 & $6.17 \mathrm{~b}$ & $4.95 b$ & 6.56 & 5.66 & 12.46 \\
\hline $\mathrm{O} 612 \mathrm{P}$ & $9.58 \mathrm{ab}$ & $6.25 b$ & $6.32 \mathrm{~b}$ & 6.85 & 5.97 & 12.82 \\
\hline T $2 \mathrm{G}$ & 7.50 & 5.52 & $4.28 b$ & 6.75 & 6.96 & 11.93 \\
\hline $\mathrm{CON} 2 \mathrm{G}$ & $10.41 \mathrm{ab}$ & $5.73 b$ & $4.73 b$ & 6.75 & 6.60 & 12.76 \\
\hline Forest & $15.19 \mathrm{a}$ & $17.85 \mathrm{a}$ & $16.02 \mathrm{a}$ & $11.81 \mathrm{a}$ & $10.68 \mathrm{a}$ & $21.13 a$ \\
\hline Haymaking & $16.00 \mathrm{~b}$ & $12.97 \mathrm{~b}$ & $6.99 \mathrm{~b}$ & $9.39 \mathrm{~b}$ & $8.88 b$ & $18.62 b$ \\
\hline
\end{tabular}

Note. Means followed by the same lowercase letter in the column do not differ statistically by the Dunnett test (5\%), from controls, means without letter are diffrent from controls. O 139: Oat 139; EO: Esmeralda Oat; O 61: Oat 61; T: Triticale; CON: Consortium; WG: Without Grazing; 1G: 1 Grazing: 2G: 2 Grazing.

High values of POC $\left(16.78 \mathrm{~g} \mathrm{~kg}^{-1}\right)$ were found in the Forest area in the superficial layer, with decreasing values in depth, $44.56 \%$ smaller between the layer of 0.05 and $0.1-0.2 \mathrm{~m}$ (Table 1). Similar results were found by Batista et al. (2013) and Carmo et al. (2012), in which the authors verified that the levels of POC were decreasing in depth, due to the accumulation of organic matter on the surface. Organic matter has its decomposition on the surface layer of the soil, which means minimum soil disturbance. We observed that the POC was efficient to show differences between the analyzed areas, in comparison with the TOC. Similar results were observed by Loss et al. (2009), Carmo et al. (2012) and Batista et al. (2013). Thus, POC can be used as an indicator of the quality of soil organic matter in relation to management changes in a shortterm period (LOSS et al., 2009).

The non-formation of a gradient of POC in depth in the ICLS areas under consolidation is a negative effect of the conventional planting system, which was practiced in the area. The plow and gradation incorporate plant residues in greater depths, promoting lower contents of POC in surface (LOSS et al., 2014). Besides that, POC is the fraction of soil organic matter that can be rapidly decomposed (BATISTA et al., 2013). However, higher POC values were observed, with the exception of the Forest, is due to the use of Poaceae, which has an abundant root system at this depth that 
contributes to the increase the organic matter (CARMO et al., 2012; LOSS et al., 2014).

It is indicated the use of crops, such as oats, with have a large biomass remaining, both in surface and in depth layers of the soil, in addition to having a high carbon/nitrogen ratio. The contribution of organic material larger than $53 \mu \mathrm{m}$, associated with smaller decomposition of the plant residues, contributes to the maintenance or increase of POC (CONCEIÇÃO et al., 2014).

Significant changes were observed for OCAM contents, with the levels that tend to increase in depth and different behavior of the POC. The higher OCAM levels in depth may be associated with the greater stability of subsurface aggregates, which contributes to greater stabilization of SOM (FACCIN et al., 2016) (Table 1). Higher OCAM levels (17.85 and $\left.16.02 \mathrm{~kg} \mathrm{~kg}^{-1}\right)$ were found in the Forest area because if there is a high OCAM participation in the organic $\mathrm{C}$, it means that in the area there is a great stabilization of the $\mathrm{C}$ and probably a decrease of $\mathrm{CO}_{2}$ emission (BATISTA et al., 2013). In addition, higher carbon contents in the most recalcitrant fractions in Oxisols can be explained by the association of organic matter with the clays, forming organomineral complexes (FACCIN et al., 2016). However, OCAM is not always a good indicator of the effect of management on soil properties, since changes in soil properties may take many years to be detected (CARMO et al., 2012).

Lower levels of OCAM were found in the ICLS area, in the $0-0.05 \mathrm{~m}$ layer, in relation to the controls, similar results were found by Loss et al. (2014). This is due to the use of practices such as the plowing and harrowing, that produce breaks in soil aggregates, exposing the organic matter protected in its interior to the attack of microorganisms, which is rapidly mineralized, causing decrease in the contents of OCAM levels.

For TOCst, the highest and significant values were found in the Forest area, followed by the Haymaking area, and the lowest in the ICLS area. These results were similar to the values obtained by other authors (ROZANE et al., 2010; GATTO et al., 2010; DORTZBACH et al., 2015), were the higher contents of TOCst are due to the greater contribution of organic matter material. The smaller stocks are possibly due to the lower contribution of residues of the vegetal biomass and/or consequence of the cultivation of grains (SANTOS et al., 2013b) and little or no grazing of animals.

However, more significant changes were found for POCst, taking into account the TOCst and
OCAMst (Table 2). As for this variable, the values found for most of the ICLS area management tend to approach the Forest area. This shows the importance of the quantification of POCst, as an indicator, by the greater sensitivity with different soil management in a short period of time (SCHIAVO et al., 2011; BATISTA et al., 2013). POCst, both positive and negative changes, are due to variations and contributions of plant residues (SCHIAVO et al., 2011; SANTOS et al., 2013b),

Few significant changes in the OCAMst were found for the area of ICLS in relation to the areas of Forest and Haymaking (Table 2). Low values for OCAMst are generally due to changes in soil management, for a short period, result in small changes in the organic matter content associated with the soil minerals that consequently OCAMst (SCHIAVO et al. 2011). Higher OCAMst in the reference areas can also be explained by the advanced stage of humification of organic matter, which becomes highly stable (SCHIAVO et al., 2011) and by the higher clay content in Oxisols, favoring the formation of stable aggregates, which would hamper both decomposition and mineralization of soil organic fractions (GATTO et al., 2010). Results similar to this work were found by Batista et al. (2013), evaluating the OCAMst under ICLS area in the Cerrado, no differences were verified regarding the in-depth.

For the CSI, the highest values observed were for the Forest, because the CSI reflects the relationship between the stocks of the management systems evaluated to the reference system, in this case the native Forest, and only the triticale without grazing in the 0.05-0.1 $\mathrm{m}$ was equal to it (Table 2 ). The CSI in this work follows the behavior of the TOC, being the values of the Forest superior to most of the other managements, a result similar to those obtained by Kunde et al. (2016).

Only in the $0.1-0.2 \mathrm{~m}$ layer in relation to the Forest, significant changes were found for LAB in the ICLS area (Table 2). In the 0-0.05 m layer the highest value for LAB (1.20) was found in the Forest area, and at the other depths (0.05-0.1 and $0.1-0.2 \mathrm{~m})$ the highest values (0.75 and 1.98) were to the Haymaking area. $\mathrm{C}$ increase in the fraction of soil is desirable, since it is the most dynamic fraction of the SOM, which is reflected in the quality of the soil (CONTE et al., 2011).

The highest levels of $\mathrm{C}$ in more labile fractions are directly associated with the higher content of plant residues (LEITE et al., 2013), altering the ratio of labile organic matter to nonlabile organic matter (KUNDE et al., 2016). 
Table 2. Mean values of particulate organic carbon stock (POCst), carbon stock associated with minerals (OCAMst), carbon stock index (CSI) and lability (LAB) in different management systems

\begin{tabular}{|c|c|c|c|c|c|c|}
\hline \multirow{2}{*}{ Management } & \multicolumn{3}{|c|}{ POCst $\mathrm{Mg} \mathrm{ha}{ }^{-1}$} & \multicolumn{3}{|c|}{ OCAMst $\mathrm{Mg} \mathrm{ha}^{-1}$} \\
\hline & $0-0.05 \mathrm{~m}$ & $0.05-0.1 \mathrm{~m}$ & $0.1-0.2 \mathrm{~m}$ & $0-0.05 \mathrm{~m}$ & $0.05-0.1 \mathrm{~m}$ & $0.1-0.2 \mathrm{~m}$ \\
\hline O $139 \mathrm{WG}$ & $4.33 \mathrm{ab}$ & $3.94 \mathrm{ab}$ & $8.88 \mathrm{a}$ & 2.39 & 2.12 & $3.60 \mathrm{~b}$ \\
\hline EO WG & $3.87 \mathrm{ab}$ & $4.75 \mathrm{ab}$ & $11.16 b$ & $2.98 \mathrm{a}$ & 1.90 & 2.35 \\
\hline O $61 \mathrm{WG}$ & $4.55 \mathrm{ab}$ & $3.94 \mathrm{ab}$ & $11.04 \mathrm{~b}$ & 2.74 & $2.80 \mathrm{~b}$ & 2.59 \\
\hline T WG & $3.59 \mathrm{ab}$ & $3.99 \mathrm{ab}$ & $8.66 \mathrm{a}$ & $3.35 \mathrm{ab}$ & $2.70 \mathrm{~b}$ & 3.10 \\
\hline CON WG & $3.88 \mathrm{ab}$ & $3.37 \mathrm{ab}$ & $8.89 \mathrm{a}$ & 2.60 & $2.81 \mathrm{~b}$ & $4.86 b$ \\
\hline O $1391 \mathrm{G}$ & $3.36 \mathrm{ab}$ & $3.73 \mathrm{ab}$ & $9.62 \mathrm{ab}$ & $2.85 \mathrm{a}$ & $2.31 \mathrm{~b}$ & 3.28 \\
\hline EO $1 \mathrm{G}$ & $3.96 a b$ & $4.07 \mathrm{ab}$ & $9.06 \mathrm{a}$ & 2.19 & 1.97 & 1.73 \\
\hline $\mathrm{O} 611 \mathrm{G}$ & $4.20 \mathrm{ab}$ & $3.91 \mathrm{ab}$ & $12.31 \mathrm{~b}$ & 2.52 & 1.88 & 0.51 \\
\hline $\mathrm{T} 1 \mathrm{G}$ & $4.99 \mathrm{ab}$ & $5.14 \mathrm{ab}$ & $9.54 \mathrm{ab}$ & 2.18 & 1.42 & 3.37 \\
\hline $\mathrm{CON} 1 \mathrm{G}$ & $2.71 b$ & $4.19 \mathrm{ab}$ & $11.34 b$ & $3.31 \mathrm{ab}$ & 1.52 & 1.01 \\
\hline O $1392 \mathrm{G}$ & $4.59 \mathrm{ab}$ & $4.08 \mathrm{ab}$ & $6.57 b$ & 2.56 & 1.77 & $5.28 b$ \\
\hline $\mathrm{EO} 2 \mathrm{G}$ & $4.59 \mathrm{ab}$ & $3.79 \mathrm{ab}$ & $9.04 \mathrm{a}$ & 1.97 & 1.87 & 3.42 \\
\hline $\mathrm{O} 612 \mathrm{P}$ & $3.71 \mathrm{ab}$ & $4.04 \mathrm{ab}$ & $8.29 \mathrm{a}$ & $3.14 \mathrm{ab}$ & 1.93 & $4.53 b$ \\
\hline T $2 \mathrm{G}$ & $4.31 \mathrm{ab}$ & $5.21 \mathrm{ab}$ & $8.92 \mathrm{a}$ & 2.43 & 1.75 & 3.01 \\
\hline $\mathrm{CON} 2 \mathrm{G}$ & $3.55 \mathrm{ab}$ & $4.78 \mathrm{ab}$ & $9.30 \mathrm{ab}$ & $3.20 \mathrm{ab}$ & 1.82 & 3.46 \\
\hline Forest & $6.20 \mathrm{a}$ & $3.65 \mathrm{a}$ & $6.51 \mathrm{a}$ & $5.61 \mathrm{a}$ & $7.03 \mathrm{a}$ & $14.62 \mathrm{a}$ \\
\hline \multirow[t]{2}{*}{ Haymaking } & $3.48 \mathrm{~b}$ & $3.77 \mathrm{~b}$ & $12.24 \mathrm{~b}$ & $5.91 \mathrm{~b}$ & $5.11 \mathrm{~b}$ & $6.38 \mathrm{~b}$ \\
\hline & \multicolumn{3}{|c|}{ CSI } & \multicolumn{3}{|c|}{ LAB } \\
\hline O $139 \mathrm{WG}$ & 0.62 & $0.75 b$ & $0.76 \mathrm{~b}$ & 0.15 & 0.19 & 0.18 \\
\hline EO WG & $0.73 b$ & $0.81 \mathrm{~b}$ & $0.82 b$ & 0.16 & 0.21 & $0.22 \mathrm{a}$ \\
\hline O $61 \mathrm{WG}$ & 0.65 & $0.83 b$ & $0.83 b$ & 0.20 & 0.21 & $0.23 \mathrm{a}$ \\
\hline T WG & $0.73 b$ & $0.87 \mathrm{ab}$ & 0.72 & 0.17 & 0.21 & 0.21 \\
\hline CON WG & $0.67 b$ & $0.74 b$ & $0.83 b$ & 0.18 & 0.21 & 0.18 \\
\hline O $1391 \mathrm{G}$ & $0.66 \mathrm{~b}$ & $0.74 b$ & $0.80 \mathrm{~b}$ & 0.21 & 0.22 & 0.19 \\
\hline EO $1 \mathrm{G}$ & $0.67 b$ & $0.74 b$ & 0.68 & 0.25 & 0.25 & $0.23 \mathrm{a}$ \\
\hline O $611 \mathrm{G}$ & 0.65 & $0.71 \mathrm{~b}$ & $0.76 \mathrm{~b}$ & 0.23 & 0.21 & $0.27 \mathrm{a}$ \\
\hline $\mathrm{T} 1 \mathrm{G}$ & $0.68 b$ & $0.79 b$ & $0.79 \mathrm{~b}$ & 0.23 & 0.25 & $0.24 \mathrm{a}$ \\
\hline $\mathrm{CON} 1 \mathrm{G}$ & 0.64 & $0.71 b$ & 0.72 & 0.26 & 0.23 & $0.23 \mathrm{a}$ \\
\hline O $1392 \mathrm{G}$ & $0.69 b$ & $0.72 b$ & $0.73 b$ & 0.22 & 0.23 & 0.20 \\
\hline EO $2 \mathrm{G}$ & $0.66 \mathrm{~b}$ & $0.69 \mathrm{~b}$ & $0.77 b$ & 0.22 & 0.20 & $0.22 \mathrm{a}$ \\
\hline $\mathrm{O} 612 \mathrm{P}$ & $0.66 \mathrm{~b}$ & $0.71 b$ & $0.76 \mathrm{~b}$ & 0.19 & 0.20 & 0.19 \\
\hline T $2 \mathrm{G}$ & 0.65 & $0.81 \mathrm{~b}$ & 0.72 & 0.23 & 0.24 & $0.23 \mathrm{a}$ \\
\hline $\mathrm{CON} 2 \mathrm{G}$ & 0.69 & $0.77 \mathrm{~b}$ & $0.74 b$ & 0.24 & 0.23 & 0.21 \\
\hline Forest & $1.00 \mathrm{a}$ & $1.00 \mathrm{a}$ & $1.00 \mathrm{a}$ & $1.20 \mathrm{a}$ & $0.52 \mathrm{a}$ & $0.45 a$ \\
\hline Haymaking & $0.80 \mathrm{~b}$ & $0.83 \mathrm{~b}$ & $0.87 \mathrm{~b}$ & $0.59 \mathrm{~b}$ & $0.75 \mathrm{~b}$ & $1.98 \mathrm{~b}$ \\
\hline
\end{tabular}

Note. Means followed by the same lowercase letter in the column do not differ statistically by the Dunnett test (5\%), from controls, means without letter are diffrent from controls. O 139: Oat 139; EO: Emeralda Oat; O 61: Oat 61; T: Triticale; CON: Consortium; WG: Without Grazing; 1G: 1 Grazing: 2G: 2 Grazing.

The labile fractions, besides being a source of nutrients for plants and an energy source for microorganisms (LEAL et al., 2015), they are important for short-term carbon and nutrient cycle, in addition to their remarkable contribution to the formation and transitory stabilization of aggregates (SANTOS et al., 2013b).

Regardless of the management adopted in the ICLS area, the LABI tended to be intermediate between the controls in all layers (Table 3). Conceição et al. (2014), evaluated conservationist systems, among which are no-tillage, and he also found LABI near the reference. This result was found by Leal et al. (2015), who evaluated the LABI in perennial grass areas. They found the LABI higher than that of the Forest (control) in all treatments.

For the CMI, the values found were, for most of the management systems, the same as those of Forest, which was the reference area (100) (Table $3)$. The importance of CMI, suggested by Blair, Lefroy and Lisle (1995) is that it takes into account aspects of the lability of soil organic matter and allows to compare the changes that occur in TOC and labile carbon (LC) as a consequence of the use and management of the soil. It is an indicator of the 
quality of soil management and allows to evaluate the process or the gain of soil quality, since the bigger the CMI, the greater it is quality and vice versa (SOUZA et al., 2009). However, the efficiency of a management system to recover soil quality depends, in addition to the characteristics of this management, on the degradation process in which the soil is found (REIS; LIMA; BAMBERG, 2016).

Table 3. Mean values of lability of index (LABI), carbon management index (CMI), and fractions oxidizable organic carbon (F1e F2) in different management systems.

\begin{tabular}{|c|c|c|c|c|c|c|}
\hline \multirow{2}{*}{ Management } & \multicolumn{3}{|c|}{ LABI } & \multicolumn{3}{|c|}{ CMI } \\
\hline & $0-0.05 \mathrm{~m}$ & $0.05-0.1 \mathrm{~m}$ & $0.1-0.2 \mathrm{~m}$ & $0-0.05 \mathrm{~m}$ & $0.05-0.1 \mathrm{~m}$ & $0.1-0.2 \mathrm{~m}$ \\
\hline O $139 \mathrm{WG}$ & $4.84 a b$ & $3.91 \mathrm{ab}$ & $5.93 \mathrm{ab}$ & $284.74 a b$ & $293.42 \mathrm{ab}$ & $444.59 \mathrm{ab}$ \\
\hline EO WG & $1.36 \mathrm{ab}$ & $5.26 \mathrm{ab}$ & 12.38 & $101.61 \mathrm{ab}$ & $427.08 \mathrm{ab}$ & $525.27 \mathrm{ab}$ \\
\hline O $61 \mathrm{WG}$ & $1.72 \mathrm{ab}$ & $3.03 \mathrm{ab}$ & $6.90 \mathrm{ab}$ & $110.72 \mathrm{ab}$ & $250.38 \mathrm{ab}$ & $580.15 \mathrm{ab}$ \\
\hline T WG & $1.10 \mathrm{ab}$ & $3.18 \mathrm{ab}$ & 7.89ab & $78.03 \mathrm{ab}$ & $277.43 \mathrm{ab}$ & $555.62 \mathrm{ab}$ \\
\hline CON WG & $1.60 \mathrm{ab}$ & $2.74 \mathrm{ab}$ & $3.96 \mathrm{ab}$ & $106.23 \mathrm{ab}$ & 205.97ab & $330.76 a b$ \\
\hline O $1391 \mathrm{G}$ & $1.15 \mathrm{ab}$ & $3.58 \mathrm{ab}$ & $8.02 \mathrm{ab}$ & $75.57 \mathrm{ab}$ & $264.41 \mathrm{ab}$ & $646.82 \mathrm{ab}$ \\
\hline EO $1 \mathrm{G}$ & $1.91 \mathrm{ab}$ & $7.25 \mathrm{ab}$ & 12.28 & $127.89 \mathrm{ab}$ & $562.05 \mathrm{ab}$ & $426.47 \mathrm{ab}$ \\
\hline $\mathrm{O} 611 \mathrm{G}$ & $2.17 \mathrm{ab}$ & $4.97 \mathrm{ab}$ & 19.33 & $130.89 \mathrm{ab}$ & $356.10 \mathrm{ab}$ & $661.31 \mathrm{ab}$ \\
\hline $\mathrm{T} 1 \mathrm{G}$ & $3.44 \mathrm{ab}$ & $8.47 \mathrm{ab}$ & $6.71 \mathrm{ab}$ & $227.50 \mathrm{ab}$ & $705.37 \mathrm{~b}$ & $553.26 \mathrm{ab}$ \\
\hline CON $1 \mathrm{G}$ & $0.82 \mathrm{ab}$ & $6.93 \mathrm{ab}$ & 12.90 & $52.02 \mathrm{ab}$ & $506.72 \mathrm{ab}$ & $444.59 \mathrm{ab}$ \\
\hline O $1392 \mathrm{G}$ & $2.25 \mathrm{ab}$ & $7.97 \mathrm{ab}$ & $4.59 \mathrm{ab}$ & $151.29 \mathrm{ab}$ & $533.10 \mathrm{ab}$ & $351.48 \mathrm{ab}$ \\
\hline $\mathrm{EO} 2 \mathrm{G}$ & $5.90 \mathrm{ab}$ & $6.01 \mathrm{ab}$ & 7.17ab & $348.31 \mathrm{ab}$ & $390.31 \mathrm{ab}$ & $524.25 \mathrm{ab}$ \\
\hline $\mathrm{O} 612 \mathrm{P}$ & $1.15 \mathrm{ab}$ & 4.89ab & $4.02 \mathrm{ab}$ & $75.88 \mathrm{ab}$ & $357.31 \mathrm{ab}$ & $302.84 \mathrm{ab}$ \\
\hline $\mathrm{T} 2 \mathrm{G}$ & $2.15 \mathrm{ab}$ & 7.13ab & $6.90 \mathrm{ab}$ & $135.36 \mathrm{ab}$ & $587.98 \mathrm{ab}$ & $495.03 \mathrm{ab}$ \\
\hline $\mathrm{CON} 2 \mathrm{G}$ & $1.31 \mathrm{ab}$ & $6.59 \mathrm{ab}$ & $6.21 \mathrm{ab}$ & $88.07 \mathrm{ab}$ & $508.94 \mathrm{ab}$ & $456.53 \mathrm{ab}$ \\
\hline Forest & $1.00 \mathrm{a}$ & $1.00 \mathrm{a}$ & $1.00 \mathrm{a}$ & $100.00 \mathrm{a}$ & $100.00 \mathrm{a}$ & $100.00 \mathrm{a}$ \\
\hline \multirow[t]{2}{*}{ Haymaking } & $0.57 \mathrm{~b}$ & $1.55 \mathrm{~b}$ & $4.27 \mathrm{~b}$ & $47.26 \mathrm{~b}$ & $129.76 b$ & $369.17 b$ \\
\hline & \multicolumn{3}{|c|}{$\mathrm{F} 1 \mathrm{~g} \mathrm{~kg}^{-1}$} & \multicolumn{3}{|c|}{$\mathrm{F} 2 \mathrm{~g} \mathrm{~kg}^{-1}$} \\
\hline O $139 \mathrm{WG}$ & $7.02 \mathrm{ab}$ & $6.00 \mathrm{ab}$ & $6.58 \mathrm{ab}$ & $4.71 \mathrm{ab}$ & $5.25 \mathrm{ab}$ & $4.07 \mathrm{ab}$ \\
\hline EO WG & $5.20 \mathrm{~b}$ & $4.20 \mathrm{ab}$ & $3.22 \mathrm{a}$ & $6.59 \mathrm{ab}$ & $5.71 \mathrm{ab}$ & $5.68 \mathrm{ab}$ \\
\hline O $61 \mathrm{WG}$ & $7.26 \mathrm{ab}$ & 7.68ab & $7.45 \mathrm{ab}$ & $4.50 \mathrm{ab}$ & $3.89 b$ & $2.54 \mathrm{~b}$ \\
\hline T WG & $8.49 \mathrm{ab}$ & $7.42 \mathrm{ab}$ & $6.28 \mathrm{ab}$ & $5.04 \mathrm{ab}$ & $3.76 b$ & $2.54 b$ \\
\hline CON WG & $4.68 b$ & $3.79 \mathrm{ab}$ & $3.62 \mathrm{a}$ & $5.52 \mathrm{ab}$ & $5.49 \mathrm{ab}$ & $5.33 \mathrm{ab}$ \\
\hline O $1391 \mathrm{G}$ & 3.81 & $4.27 \mathrm{ab}$ & $3.61 \mathrm{a}$ & $6.53 \mathrm{ab}$ & $3,74 b$ & $4.35 \mathrm{ab}$ \\
\hline EO $1 \mathrm{G}$ & $5.78 b$ & $4.84 \mathrm{ab}$ & $4.09 \mathrm{ab}$ & $4.20 \mathrm{ab}$ & $5.01 \mathrm{ab}$ & $4.25 \mathrm{ab}$ \\
\hline $\mathrm{O} 611 \mathrm{G}$ & $5.03 \mathrm{~b}$ & $4.70 \mathrm{ab}$ & $4.14 \mathrm{ab}$ & $4,11 b$ & $5.55 \mathrm{ab}$ & $5.28 \mathrm{ab}$ \\
\hline $\mathrm{T} 1 \mathrm{G}$ & $5.03 \mathrm{~b}$ & $5.13 \mathrm{ab}$ & $3.97 \mathrm{ab}$ & $4.59 \mathrm{ab}$ & $1.43 \mathrm{~b}$ & $5.28 \mathrm{ab}$ \\
\hline CON $1 G$ & $4.77 b$ & $5.17 \mathrm{ab}$ & $4.20 \mathrm{ab}$ & $5.39 \mathrm{ab}$ & $4.66 \mathrm{ab}$ & $4.67 \mathrm{ab}$ \\
\hline O $1392 \mathrm{G}$ & $6.41 \mathrm{ab}$ & $5.17 \mathrm{ab}$ & $4.92 \mathrm{ab}$ & $5.42 \mathrm{ab}$ & $6.65 \mathrm{ab}$ & $5.00 \mathrm{ab}$ \\
\hline EO $2 \mathrm{G}$ & 3.46 & $4.33 \mathrm{ab}$ & 4.18ab & $5.48 \mathrm{ab}$ & $4.58 \mathrm{ab}$ & $4.67 \mathrm{ab}$ \\
\hline $\mathrm{O} 612 \mathrm{P}$ & $5.67 \mathrm{~b}$ & $4.33 \mathrm{ab}$ & $4.04 \mathrm{ab}$ & $6.86 \mathrm{ab}$ & $6.35 \mathrm{ab}$ & $6.31 \mathrm{a}$ \\
\hline $\mathrm{T} 2 \mathrm{G}$ & $5.60 \mathrm{~b}$ & $5.42 \mathrm{ab}$ & $4.16 a b$ & $5.96 a b$ & $3.71 b$ & $7.32 \mathrm{a}$ \\
\hline $\mathrm{CON} 2 \mathrm{G}$ & $5.21 \mathrm{~b}$ & $4.67 \mathrm{ab}$ & $3.64 \mathrm{a}$ & $6.40 \mathrm{ab}$ & $6.52 \mathrm{ab}$ & $6.22 \mathrm{a}$ \\
\hline Forest & $8.24 a$ & $5.83 a$ & $5.42 \mathrm{a}$ & $8.64 a$ & $9.08 \mathrm{a}$ & $7.37 \mathrm{a}$ \\
\hline Haymaking & $6.67 \mathrm{~b}$ & $6.04 \mathrm{~b}$ & $6.10 \mathrm{~b}$ & $3.93 b$ & $2.83 \mathrm{~b}$ & $1.66 \mathrm{~b}$ \\
\hline
\end{tabular}

Note. Means followed by the same lowercase letter in the column do not differ statistically by the Dunnett test (5\%), from controls, means without letter are diffrent from controls. O 139: Oat 139; EO: Emeralda Oat; O 61: Oat 61; T: Triticale; CON: Consortium; WG: Without Grazing; 1G: 1 Grazing: 2G: 2 Grazing.

For the CMI, the values found were, for most of the same managements as that of Rossi et al. (2012), evaluating CMI as a soil quality indicator, in the area Cerrado Goiano, in a dystrophic Red Latosol, also at high CMI values (905) with soybean and Brachiaria under no-tillage, demonstrating that the evaluated systems are being maintenance of carbon stocks. Souza et al. (2009), evaluating CMI in a ICLS in no-tillage, also found high CMI values (256), with the Forest as reference (100), due to the management with greater plant residues.

Corroborating with this work, Gazolla et al. (2015), found the highest values of CMI in the area of ICLS, due to the higher contributions of organic matter by the grass root system (corn and Brachiaria), especially the Brachiaria crop. However, for Balin et al. (2017), evaluating the 
CMI of a Red Latosol under different systems of use, found that $\mathrm{LAB}, \mathrm{LABI}$, and CMI values were lower in the ICLS area compared to the reference area (Forest). However, present potential for $\mathrm{C}$ preservation and recovery in their compartments compared to more conservationist systems.

The levels of $\mathrm{C}$ of the oxidative fractions and their respective ratios are shown in Tables 3 and 4. In the $0-0.05 \mathrm{~cm}$ layer, the oats 139 , oats 61 and the triticale without grazing together with the oats 139 presented levels of $\mathrm{C}$ in the $\mathrm{F} 1$ fractions of the
LC equal to those of the controls, since the other management of the ICLS area is equal only to the area of Haymaking. For the F1 fraction, in the other depths $(0.05-0.1$ and $0.1-0.2 \mathrm{~m})$ the mean levels of this fraction tend to be intermediate between the reference areas. For F2 and F4 fractions, at all depths, the studied managements tend to be similar in the reference areas. However, for the F3 levels of managements, in all depths, they tend to resemble the Forest.

Table 4. Mean values of the oxidizable fractions of organic carbon (F3 and F4) and the relation between the oxidizable fractions $\mathrm{F} 1 / \mathrm{F} 4,(\mathrm{~F} 1+\mathrm{F} 2) /(\mathrm{F} 3+\mathrm{F} 4)$ in the different management systems.

\begin{tabular}{|c|c|c|c|c|c|c|}
\hline \multirow{2}{*}{ Management } & \multicolumn{3}{|c|}{$\mathrm{F} 3 \mathrm{~g} \mathrm{~kg}^{-1}$} & \multicolumn{3}{|c|}{$\mathrm{F} 4 \mathrm{~g} \mathrm{~kg}^{-1}$} \\
\hline & $0-0.05 \mathrm{~m}$ & $0.05-0.1 \mathrm{~m}$ & $0.1-0.2 \mathrm{~m}$ & $0-0.05 \mathrm{~m}$ & $0.05-0.1 \mathrm{~m}$ & $0.1-0.2 \mathrm{~m}$ \\
\hline O $139 \mathrm{WG}$ & $4.56 \mathrm{a}$ & $3.42 \mathrm{a}$ & $3.43 \mathrm{a}$ & $3.54 \mathrm{ab}$ & $5.78 \mathrm{ab}$ & $3.83 \mathrm{ab}$ \\
\hline EO WG & $6.09 \mathrm{ab}$ & $5.56 \mathrm{ab}$ & $4.70 \mathrm{a}$ & $5.34 a b$ & $6.46 a b$ & $5.65 \mathrm{ab}$ \\
\hline O $61 \mathrm{WG}$ & 3.01 & $3.12 \mathrm{a}$ & $2.72 \mathrm{a}$ & $5.84 a b$ & 7.78ab & $6.73 \mathrm{ab}$ \\
\hline T WG & 3.63 & $4.17 \mathrm{a}$ & $4.45 \mathrm{a}$ & $5.89 \mathrm{ab}$ & 7.80ab & $3.71 \mathrm{ab}$ \\
\hline CON WG & $6.10 \mathrm{ab}$ & $5.80 \mathrm{ab}$ & $5.27 \mathrm{ab}$ & $5.04 \mathrm{ab}$ & $4.94 a b$ & $5.39 \mathrm{ab}$ \\
\hline O $1391 \mathrm{G}$ & $6.02 \mathrm{ab}$ & $5.66 \mathrm{ab}$ & $4.27 \mathrm{a}$ & $4.44 \mathrm{ab}$ & $6.42 \mathrm{ab}$ & $6.48 \mathrm{ab}$ \\
\hline EO $1 \mathrm{G}$ & $5.80 \mathrm{ab}$ & $3.96 \mathrm{a}$ & $5.58 \mathrm{ab}$ & $5.41 \mathrm{ab}$ & $6.31 \mathrm{ab}$ & $2.16 \mathrm{ab}$ \\
\hline O $611 \mathrm{G}$ & $6.65 \mathrm{ab}$ & $3.80 \mathrm{a}$ & $4.30 \mathrm{a}$ & $4.99 \mathrm{ab}$ & $5.13 a b$ & $4.08 \mathrm{ab}$ \\
\hline $\mathrm{T} 1 \mathrm{G}$ & $5.44 \mathrm{ab}$ & $6.44 a b$ & $5.12 \mathrm{ab}$ & $6.39 \mathrm{ab}$ & $8.52 \mathrm{a}$ & $4.20 \mathrm{ab}$ \\
\hline $\mathrm{CON} 1 \mathrm{G}$ & 3.97 & $3.67 \mathrm{a}$ & $3.93 \mathrm{a}$ & $6.26 \mathrm{ab}$ & $5.74 a b$ & $4.09 \mathrm{ab}$ \\
\hline O $1392 \mathrm{G}$ & 3.91 & $2.52 \mathrm{a}$ & $3.88 \mathrm{a}$ & $6.26 \mathrm{ab}$ & $5.21 \mathrm{ab}$ & $3.44 a b$ \\
\hline EO 2G & $5.38 \mathrm{ab}$ & $4.64 a$ & $5.87 \mathrm{ab}$ & $6.52 \mathrm{ab}$ & $5.14 a b$ & $3.68 \mathrm{ab}$ \\
\hline O $612 \mathrm{P}$ & $5.72 \mathrm{ab}$ & $6.58 \mathrm{ab}$ & $3.89 \mathrm{a}$ & $2.65 b$ & $3.75 \mathrm{ab}$ & $3.63 \mathrm{ab}$ \\
\hline Т $2 \mathrm{G}$ & $4.21 \mathrm{a}$ & $5.01 \mathrm{a}$ & $3.04 \mathrm{a}$ & $5.01 \mathrm{ab}$ & $7.86 a b$ & $2.58 \mathrm{ab}$ \\
\hline $\mathrm{CON} 2 \mathrm{G}$ & $5.15 \mathrm{a}$ & $4.38 \mathrm{a}$ & $3.88 \mathrm{a}$ & $5.20 \mathrm{ab}$ & $5.24 \mathrm{ab}$ & $3.70 \mathrm{ab}$ \\
\hline Forest & $7.90 \mathrm{a}$ & $5.66 \mathrm{a}$ & $6.68 \mathrm{a}$ & $7.21 \mathrm{a}$ & $6.54 \mathrm{a}$ & $3.68 \mathrm{a}$ \\
\hline \multirow[t]{2}{*}{ Haymaking } & $9.21 \mathrm{~b}$ & $9.43 \mathrm{~b}$ & $8.77 \mathrm{~b}$ & $5.61 \mathrm{~b}$ & $4.02 \mathrm{~b}$ & $3.88 \mathrm{~b}$ \\
\hline & \multicolumn{3}{|c|}{$\mathrm{F} 1 / \mathrm{F} 4$} & \multicolumn{3}{|c|}{$(\mathrm{F} 1+\mathrm{F} 2) /(\mathrm{F} 3+\mathrm{F} 4)$} \\
\hline O $139 \mathrm{WG}$ & $1.62 \mathrm{ab}$ & $1.45 \mathrm{ab}$ & $1.80 \mathrm{ab}$ & $1.50 \mathrm{ab}$ & $1.23 \mathrm{ab}$ & $1.51 \mathrm{ab}$ \\
\hline EO WG & $0.78 \mathrm{ab}$ & $0.85 \mathrm{ab}$ & $0.58 \mathrm{ab}$ & $1.04 \mathrm{ab}$ & $0.85 \mathrm{ab}$ & $0.87 \mathrm{ab}$ \\
\hline O $61 \mathrm{WG}$ & $1.76 \mathrm{ab}$ & $2.23 b$ & 3.02 & $1.33 \mathrm{ab}$ & $1.07 \mathrm{ab}$ & $1.06 \mathrm{ab}$ \\
\hline T WG & $1.85 \mathrm{ab}$ & $1.73 a b$ & $2.54 \mathrm{ab}$ & $1.45 \mathrm{ab}$ & $1.13 \mathrm{ab}$ & $1.14 \mathrm{ab}$ \\
\hline CON WG & $0.87 \mathrm{ab}$ & $0.70 \mathrm{ab}$ & $0.75 \mathrm{ab}$ & $0.92 \mathrm{ab}$ & $0.87 \mathrm{ab}$ & $0.87 \mathrm{ab}$ \\
\hline O $1391 \mathrm{G}$ & $0.73 a b$ & $1.15 \mathrm{ab}$ & $1.63 \mathrm{ab}$ & $1.02 \mathrm{ab}$ & $0.66 a b$ & $0.78 \mathrm{ab}$ \\
\hline EO $1 \mathrm{G}$ & $1.47 \mathrm{ab}$ & $0.97 \mathrm{ab}$ & $0.99 \mathrm{ab}$ & $0.90 \mathrm{ab}$ & $0.96 a b$ & $1.09 \mathrm{ab}$ \\
\hline $\mathrm{O} 611 \mathrm{G}$ & $1.33 \mathrm{ab}$ & $0.87 \mathrm{ab}$ & $0.79 \mathrm{ab}$ & $0.85 \mathrm{ab}$ & $1.15 \mathrm{ab}$ & $1.12 \mathrm{ab}$ \\
\hline $\mathrm{T} 1 \mathrm{G}$ & $1.28 \mathrm{ab}$ & 3.66 & $0.79 \mathrm{ab}$ & $0.81 \mathrm{ab}$ & $0.45 \mathrm{ab}$ & $1.07 \mathrm{ab}$ \\
\hline CON $1 \mathrm{G}$ & $0.89 \mathrm{ab}$ & $1.19 \mathrm{ab}$ & $0.90 \mathrm{ab}$ & $1.03 \mathrm{ab}$ & $1.07 \mathrm{ab}$ & $1.14 \mathrm{ab}$ \\
\hline O $1392 \mathrm{G}$ & $1.19 \mathrm{ab}$ & $0.79 \mathrm{ab}$ & $1.01 \mathrm{ab}$ & $1.20 \mathrm{ab}$ & $1.56 \mathrm{ab}$ & $1.47 \mathrm{ab}$ \\
\hline EO 2G & $0.73 \mathrm{ab}$ & $0.94 \mathrm{ab}$ & $0.94 \mathrm{ab}$ & $0.76 \mathrm{ab}$ & $0.91 \mathrm{ab}$ & $1.00 \mathrm{ab}$ \\
\hline O $612 \mathrm{P}$ & $0.84 \mathrm{ab}$ & $0.73 \mathrm{ab}$ & $0.66 \mathrm{ab}$ & $1.54 \mathrm{ab}$ & $1.09 \mathrm{ab}$ & $1.39 \mathrm{ab}$ \\
\hline Т $2 \mathrm{G}$ & $1.10 \mathrm{ab}$ & $1.47 \mathrm{ab}$ & $0.61 \mathrm{ab}$ & $1.30 \mathrm{ab}$ & $0.72 \mathrm{ab}$ & 3.08 \\
\hline CON 2G & $0.89 \mathrm{ab}$ & $0.77 \mathrm{ab}$ & $0.62 \mathrm{ab}$ & $1.15 \mathrm{ab}$ & $1.18 \mathrm{ab}$ & $1.41 \mathrm{ab}$ \\
\hline Forest & $1.14 \mathrm{a}$ & $0.95 \mathrm{a}$ & $1.52 \mathrm{a}$ & $1.12 \mathrm{a}$ & $1.22 \mathrm{a}$ & $1.24 \mathrm{a}$ \\
\hline Haymaking & $1.32 \mathrm{~b}$ & $1.51 \mathrm{~b}$ & $1.58 \mathrm{~b}$ & $0.74 b$ & $0.66 \mathrm{~b}$ & $0.62 \mathrm{~b}$ \\
\hline
\end{tabular}

Note. Means followed by the same lowercase letter in the column do not differ statistically by the Dunnett test (5\%), from controls, means without letter are diffrent from controls. O 139: Oat 139; EO: Emeralda Oat; O 61: Oat 61; T: Triticale; CON: Consortium; WG: Without Grazing; 1G: 1 Grazing: 2G: 2 Grazing. 
The levels of F1 and F2 in the ICLS area, similar to Forest area, tend to correlate positively with TOC, since, according to Souza et al. (2014), higher levels of LC in the fractions F1 and F2 tend to be found in areas where there is a great contribution of organic matter, from vegetal residues on the soil surface. The labile fractions of organic matter are fundamental for both the cycling of $\mathrm{C}$ between the compartments and for the cycling of nutrients in the short term, in addition to its remarkable contribution to the formation and transitory stabilization of aggregates (SANTOS et al., 2013b).

In general, for Rosset et al. (2016), the contents of the fractions F1 and F2 decrease in depth from 52 to $44 \%$ in the layers of $0-0.05$ and 0.1-0.2 m, and fractions F3 and F4 tend to increase from 48 to $56 \%$, in the above-mentioned layers. Similar results to those of Melo et al. (2016), finding higher levels of $\mathrm{C}$ in the oxidizable fractions in the 0.0-0.05 m layer, compared to the $0.05-0.1 \mathrm{~m}$ layer, are mainly due to the contribution of residues. The non-formation of layers, mainly in the agricultural area of this work, is due to the short period of transition from conventional system to ICLS. Loss et al. (2014), found lower levels of C in all fractions evaluated in the conventional system area, demonstrating the negative anthropic influence in this type of system in detriment to the Forest and no-tillage.

The fractions F3 and F4 are the most stable fractions of SOM, increasing in depth. Rosset et al. (2016) found the highest levels of $\mathrm{C}$ in fractions F3 and F4, in the 0.1-0.2 m layer, in the pasture area, due to the higher levels of HUM, a different result to this work. Melo et al. (2016), evaluating different forms of management, found lower values of $\mathrm{C}$ in fraction $\mathrm{F} 1$ by reducing soil $\mathrm{C}$ and that $\mathrm{F} 3$ and $\mathrm{F} 4$ fractions were not favored by these activities due to the lower values of these more recalcitrant fractions. Loss et al. (2014), also observed higher levels in the most stable fractions (F3 and F4) for the pasture area, in depth (0.05-0.4 m), due to the root system of the grassland and lower F4 fraction content in conventional system, due to lower OCAM levels, evidencing inadequate management (plowing and grading weeds out).

For the relative distribution between the labile and recalcitrant fractions of SOM, represented by the relations $\mathrm{F} 1 / \mathrm{F} 4$ and $(\mathrm{F} 1+\mathrm{F} 2) /(\mathrm{F} 3+\mathrm{F} 4)$, in this work, the results found in agricultural areas at all depths tend to be intermediate to the reference areas (Table 4). In this work, most of the results, from the F1/F4 ratio, are close to 1 , and for Loss et al. (2014), the closer this ratio is, the better the distribution of carbon contents between the more labile fraction (F1) and the more recalcitrant fraction (F4) in the soil.

Similar results to this work were found by Rosset et al. (2016), that when evaluating areas of no-tillage found values for the F1/F4 ratio similar to those of the Forest, which indicates a higher input of plant material of greater lability. Loss et al. (2014) also found the index values of F1/F4 upper 1, for pasture and Forest area in the soil surface layer (0$0.1 \mathrm{~m}$ ) due to higher levels of $\mathrm{C}$ in fraction $\mathrm{F} 1$ and area of no-tillage with less than 1 , due to the higher concentration of $\mathrm{C}$ in fraction 4.

When the four fractions were evaluated together $(\mathrm{F} 1+\mathrm{F} 2) /(\mathrm{F} 3+\mathrm{F} 4)$, the ICLS area stood out, with values close to the reference units, especially in the first two layers (Table 4). Similar results to this work were found by Rosset et al. (2016), that when evaluating the relationship $(\mathrm{F} 1+\mathrm{F} 2) /(\mathrm{F} 3+\mathrm{F} 4)$, in areas with no-tillage and ICLS in red eutrophic Latosol, found values lower than 1.20. However, for Martins et al. (2015), the relationship $(\mathrm{F} 1+\mathrm{F} 2) /(\mathrm{F} 3+\mathrm{F} 4)$ tends to be high in the surface horizon, indicating predominance of the most labile fractions (F1 and F2), and low in the subsurface horizon, indicating greater presence of the most recalcitrant fractions (F3 and F4), a fact not observed in this work.

The levels of $\mathrm{C}$ of the humic fractions did not show a wide variation among the management systems, and the levels of FA, HA and HUM tended to be intermediate between the reference areas (Table 5). Among the fractions, the HUM presented the highest levels regardless of management systems and depth, a similar result to that of Pulrolnik et al. (2009), evaluating soils under eucalyptus, pasture, and cerrado and for Gazolla et al. (2015), evaluating areas of pasture, no-tillage, and ICLS. Campos et al. (2013), also observed higher levels of HUM, with higher content $\left(17.60 \mathrm{~g} \mathrm{~kg}^{-1}\right)$, in the superficial layer of $0.0-0.05 \mathrm{~m}$ in the native vegetation area, a result associated with the greater amount of TOC treatment. Higher levels of HUM, in very clayey soils under tropical climate, can be also attributed to the interaction of the organic matter with the mineral fraction of this soil (PULROLNIK et al., 2009; CAMPOS et al., 2013; ROSSET et al., 2016).

Portugal et al. (2008), evaluating agricultural systems implanted in red-yellow argisol, found that the different soil uses altered the $\mathrm{C}$ content in the fractions FA, HA, HUM similarly between the systems of use, in the depths of $0-0.1 \mathrm{~m}$ and $0.1-0.2 \mathrm{~m}$, a result similar to this work. For Gazolla et al. (2015), the values of the humic substances, HUM (0.2-0.4 m), AF (0.05-0.1, 0.1-0.2 
and 0.2-0.4 m) and HA (all depths) were practically similar, between the no-tillage and ICLS areas, mainly due to the similarity of SOM dynamics. However, for Martins et al. (2015), evaluating different types of soil in Forest areas, observed that the $\mathrm{C}$ levels of the humic fractions also showed a wide variation among the studied horizons, with FA varying between 0.6 and $3.67 \mathrm{~g} \mathrm{~kg}^{-1}$, AH of 0.3 to $5.8 \mathrm{~g} \mathrm{~kg}^{-1}$ and the HUM of 3.0 to $40.8 \mathrm{~g} \mathrm{~kg}^{-1}$.

Table 5. Mean values of humidified fractions of fulvic acid (FA), humic acid (HA) and humin (HUM), humic acid and fulvic acid ratio (HA/FA) in different management systems.

\begin{tabular}{|c|c|c|c|c|c|c|}
\hline \multirow{2}{*}{ Management } & \multicolumn{3}{|c|}{$\mathrm{FA} \mathrm{g} \mathrm{kg}^{-1}$} & \multicolumn{3}{|c|}{$\mathrm{HA} \mathrm{g} \mathrm{kg}^{-1}$} \\
\hline & $0-0.05 \mathrm{~m}$ & $0.05-0.1 \mathrm{~m}$ & $0.1-0.2 \mathrm{~m}$ & $0-0.05 \mathrm{~m}$ & $0.05-0.1 \mathrm{~m}$ & $0.1-0.2 \mathrm{~m}$ \\
\hline O $139 \mathrm{WG}$ & $3.09 \mathrm{~b}$ & $2.86 \mathrm{ab}$ & $3.00 \mathrm{ab}$ & $2.68 b$ & $3.06 \mathrm{ab}$ & $3.10 \mathrm{ab}$ \\
\hline EO WG & $2.79 b$ & $2.85 \mathrm{~b}$ & $2.94 \mathrm{ab}$ & $2.95 \mathrm{~b}$ & $3.69 \mathrm{ab}$ & $3.85 \mathrm{a}$ \\
\hline O $61 \mathrm{WG}$ & $2.98 b$ & $3.19 \mathrm{ab}$ & $3.23 \mathrm{ab}$ & $3.38 \mathrm{ab}$ & $3.55 \mathrm{ab}$ & $3.76 \mathrm{a}$ \\
\hline T WG & $3.21 \mathrm{~b}$ & $3.03 \mathrm{ab}$ & $2.86 \mathrm{ab}$ & $3.30 \mathrm{~b}$ & $3.78 \mathrm{ab}$ & $3.41 \mathrm{ab}$ \\
\hline CON WG & $3.03 \mathrm{~b}$ & $2.83 b$ & $2.97 \mathrm{ab}$ & $3.21 \mathrm{~b}$ & $3.32 \mathrm{ab}$ & $3.34 \mathrm{ab}$ \\
\hline O $1391 \mathrm{G}$ & $2.98 b$ & $3.15 \mathrm{ab}$ & $3.11 \mathrm{ab}$ & $3.22 \mathrm{~b}$ & $3.44 \mathrm{ab}$ & $2.90 \mathrm{ab}$ \\
\hline EO $1 \mathrm{G}$ & $3.28 b$ & $3.38 \mathrm{ab}$ & $2.94 \mathrm{ab}$ & $3.41 \mathrm{ab}$ & $3.35 \mathrm{ab}$ & 3.19ab \\
\hline $\mathrm{O} 611 \mathrm{G}$ & $3.39 b$ & $3.03 \mathrm{ab}$ & $3.05 \mathrm{ab}$ & $3.71 \mathrm{ab}$ & $3.29 \mathrm{ab}$ & $3.48 \mathrm{ab}$ \\
\hline $\mathrm{T} 1 \mathrm{G}$ & $2.81 \mathrm{~b}$ & 3.09ab & $3.03 \mathrm{ab}$ & $3.48 \mathrm{ab}$ & $4.07 \mathrm{a}$ & $3.88 \mathrm{a}$ \\
\hline CON $1 \mathrm{G}$ & $2.97 \mathrm{~b}$ & $2.94 \mathrm{ab}$ & $2.98 \mathrm{ab}$ & $3.70 \mathrm{ab}$ & $3.34 \mathrm{ab}$ & $3.23 \mathrm{ab}$ \\
\hline O $1392 \mathrm{G}$ & $3.55 b$ & $3.20 \mathrm{ab}$ & $3.31 \mathrm{ab}$ & $3.33 \mathrm{ab}$ & $3.46 \mathrm{ab}$ & $2.96 a b$ \\
\hline EO $2 \mathrm{G}$ & $3.06 \mathrm{~b}$ & $3.20 \mathrm{ab}$ & $3.27 \mathrm{ab}$ & $2.98 b$ & $2.87 \mathrm{ab}$ & $3.04 \mathrm{ab}$ \\
\hline $\mathrm{O} 612 \mathrm{P}$ & $3.40 \mathrm{~b}$ & $3.47 \mathrm{ab}$ & $3.72 \mathrm{a}$ & $3.20 \mathrm{~b}$ & $3.44 \mathrm{ab}$ & $3.28 \mathrm{ab}$ \\
\hline $\mathrm{T} 2 \mathrm{G}$ & $3.51 \mathrm{~b}$ & $3.34 \mathrm{ab}$ & $3.27 \mathrm{ab}$ & $3.23 b$ & $3.48 \mathrm{ab}$ & $3.12 \mathrm{ab}$ \\
\hline CON $2 \mathrm{G}$ & $3.34 \mathrm{~b}$ & $3.62 \mathrm{ab}$ & $3.14 \mathrm{ab}$ & $3.52 \mathrm{ab}$ & $3.43 \mathrm{ab}$ & $3.04 \mathrm{ab}$ \\
\hline Forest & $4.53 \mathrm{a}$ & $3.64 a$ & $3.32 \mathrm{a}$ & $4.39 a$ & $3.83 a$ & $3.47 \mathrm{a}$ \\
\hline \multirow[t]{2}{*}{ Haymaking } & $3.15 \mathrm{~b}$ & $2.84 \mathrm{~b}$ & $2.60 \mathrm{~b}$ & $3.25 \mathrm{~b}$ & $2.88 \mathrm{~b}$ & $2.50 \mathrm{~b}$ \\
\hline & \multicolumn{3}{|c|}{ HUM g kg-1 } & \multicolumn{3}{|c|}{ HA/FA } \\
\hline O $139 \mathrm{WG}$ & $18.09 \mathrm{ab}$ & $16.08 \mathrm{ab}$ & $17.25 \mathrm{a}$ & $0.87 \mathrm{ab}$ & $1.11 \mathrm{ab}$ & $1.07 \mathrm{ab}$ \\
\hline EO WG & $18.32 \mathrm{ab}$ & $17.48 \mathrm{ab}$ & $17.70 \mathrm{a}$ & $1.07 \mathrm{ab}$ & $1.40 \mathrm{ab}$ & $1.45 \mathrm{ab}$ \\
\hline O $61 \mathrm{WG}$ & $17.50 \mathrm{ab}$ & $17.50 \mathrm{ab}$ & $16.84 \mathrm{a}$ & $1.17 \mathrm{ab}$ & $1.14 \mathrm{ab}$ & $1.22 \mathrm{ab}$ \\
\hline T WG & $19.86 \mathrm{ab}$ & $18.22 \mathrm{a}$ & $16.51 \mathrm{a}$ & $1.05 \mathrm{ab}$ & $1.28 \mathrm{ab}$ & $1.26 \mathrm{ab}$ \\
\hline CON WG & $18.27 \mathrm{ab}$ & $15.85 \mathrm{ab}$ & $18.20 \mathrm{a}$ & $1.09 \mathrm{ab}$ & $1.32 \mathrm{ab}$ & $1.19 \mathrm{ab}$ \\
\hline O $1391 \mathrm{G}$ & $16.22 \mathrm{ab}$ & $16.32 \mathrm{ab}$ & $15.64 \mathrm{ab}$ & $1.12 \mathrm{ab}$ & $1.10 \mathrm{ab}$ & $0.94 \mathrm{ab}$ \\
\hline EO $1 \mathrm{G}$ & $14.22 b$ & $14.02 \mathrm{ab}$ & $14.33 \mathrm{ab}$ & $1.06 \mathrm{ab}$ & $1.01 \mathrm{ab}$ & $1.14 \mathrm{ab}$ \\
\hline $\mathrm{O} 611 \mathrm{G}$ & $16.45 \mathrm{ab}$ & $15.71 \mathrm{ab}$ & $13.99 \mathrm{ab}$ & $1.10 \mathrm{ab}$ & $1.12 \mathrm{ab}$ & $1.20 \mathrm{ab}$ \\
\hline $\mathrm{T} 1 \mathrm{G}$ & $16.43 \mathrm{ab}$ & $16.57 \mathrm{ab}$ & $16.21 \mathrm{ab}$ & $1.30 \mathrm{ab}$ & $1.45 \mathrm{ab}$ & $1.40 \mathrm{ab}$ \\
\hline CON $1 \mathrm{G}$ & $14.84 b$ & $14.83 \mathrm{ab}$ & $14.74 \mathrm{ab}$ & $1.30 \mathrm{ab}$ & $1.17 \mathrm{ab}$ & $1.13 \mathrm{ab}$ \\
\hline O $1392 \mathrm{G}$ & $15.44 \mathrm{ab}$ & $15.44 \mathrm{ab}$ & $15.45 \mathrm{ab}$ & $0.94 \mathrm{ab}$ & $1.09 \mathrm{ab}$ & $0.88 \mathrm{ab}$ \\
\hline EO $2 \mathrm{G}$ & $14.21 \mathrm{~b}$ & $14.61 \mathrm{ab}$ & $13.94 \mathrm{ab}$ & $0.98 \mathrm{ab}$ & $0.90 \mathrm{ab}$ & $0.92 \mathrm{ab}$ \\
\hline $\mathrm{O} 612 \mathrm{P}$ & $17.25 \mathrm{ab}$ & $17.60 \mathrm{ab}$ & $17.43 \mathrm{a}$ & $0.95 \mathrm{ab}$ & $1.03 \mathrm{ab}$ & $0.87 \mathrm{ab}$ \\
\hline $\mathrm{T} 2 \mathrm{G}$ & $14.90 \mathrm{~b}$ & $15.09 \mathrm{ab}$ & $14.36 \mathrm{ab}$ & $0.92 \mathrm{ab}$ & $1.04 \mathrm{ab}$ & $0.96 \mathrm{ab}$ \\
\hline CON $2 \mathrm{G}$ & $15.25 \mathrm{ab}$ & $15.54 \mathrm{ab}$ & $14.79 \mathrm{ab}$ & $1.05 \mathrm{ab}$ & $0.96 \mathrm{ab}$ & $0.97 \mathrm{ab}$ \\
\hline Forest & $19.15 \mathrm{a}$ & $17.84 \mathrm{a}$ & $13.97 \mathrm{a}$ & $0.97 \mathrm{a}$ & $1.07 \mathrm{a}$ & $1.05 \mathrm{a}$ \\
\hline Haymaking & $16.40 \mathrm{~b}$ & $13.71 b$ & $11.70 \mathrm{~b}$ & $1.03 \mathrm{~b}$ & $1.02 \mathrm{~b}$ & $0.96 \mathrm{~b}$ \\
\hline
\end{tabular}

\footnotetext{
Note. Means followed by the same lowercase letter in the column do not differ statistically by the Dunnett test (5\%), from controls, means without letter are diffrent from controls. O 139: Oat 139; EO: Emeralda Oat; O 61: Oat 61; T: Triticale; CON: Consortium; WG: Without Grazing; 1G: 1 Grazing: 2G: 2 Grazing.
}

However, when the native vegetation is removed by anthropic action, important changes occur in the humic substances dynamics (PULROLNIK et al., 2009), such as soil plow in the conventional system, that accelerates the decomposition of the SOM, disfavoring the HA and benefiting the FA (LOSS et al., 2010). And the FA fraction represents the intermediate fraction in the stabilization process of the humic compounds (PORTUGAL et al., 2008).

Although agricultural use drastically decreases SOM content, agricultural systems present a different recovery to this organic behavior (PORTUGAL et al., 2008), because for Loss et al. (2010) in no-tillage areas, when there is no soil disturbance, there is an increase in the proportion of HA in relation to surface FA, since HA represents 
the intermediate fraction in the stabilization process of the humic compounds (SANTOS et al., 2013b).

For the HA/FA ratio, which expresses the degree of evolution of the humification process, in this study, the values found for the management were intermediate between the reference areas, and the ratio ranged from 0.87 to 1.45 (Table 5). In tropical soils, this ratio is lower than 1 , because the organic fraction is dominated by humic, indicating soil with intense mineralization of residues, edaphic restrictions and intensely weathered soils (CERRI; VOLKOFF, 1988; CANELLAS et al., 2003). The HA/FA ratio also indicates the degree of conversion of the insoluble organic carbon present in the soil into soluble fractions, whereas in sandy soils presented higher values for the ratio HA/FA, which means the selective loss of the most soluble fraction (MARTINS; CORINGA; WEBER, 2009).

Martins et al. (2015), found for the AH/AF ratio, in different soil types under Seasonal Deciduous Forest, values greater than 1 for most horizons, denoting the predominance of humic acids. For Martins, Coringa and Weber (2009), pasture and agroforestry systems presented the highest values for the AH/AF ratio, which indicates greater carbon mobility in these systems of land use. However, Gazolla et al. (2015), found AH/AF ratio values of the ICLS and Cerrado area close to 2, indicating that in these areas, there is a predominance of $\mathrm{HA}$ in relation to $\mathrm{FA}$, presenting a more stable organic material, evidencing more preserved soils, of more conservationist management systems.

The results found for the AE, in the $0-0.05$ $\mathrm{m}$ layer, were for all management systems lower than Forest, and in the other layers the results were the same or intermediate the reference areas (Table 6). However, Campos et al. (2013), found values of $\mathrm{AE}$, lower in the 0-0.05 $\mathrm{m}$ depth layer, for the Forest area and in the other layers the results were the same or intermediate for the management systems in relation to the reference areas. Although $\mathrm{AE}$ indicates the degree of conversion of insoluble organic $\mathrm{C}$ from soil to soluble fractions, for these authors, lower values of AE, in soils under native vegetation and pastures are due to the composition of plant residues being poor in lignin.

Table 6. Mean values of alkaline extract (AE) and the relation between alkaline extract/humic (AE/HUM), in the different management systems.

\begin{tabular}{|c|c|c|c|c|c|c|}
\hline \multirow{2}{*}{ Management } & \multicolumn{3}{|c|}{$\mathrm{AE} \mathrm{g} \mathrm{kg}^{-1}$} & \multicolumn{3}{|c|}{ AE/HUM } \\
\hline & $0-0.05 \mathrm{~m}$ & $0.05-0.1 \mathrm{~m}$ & $0.1-0.2 \mathrm{~m}$ & $0-0.05 \mathrm{~m}$ & $0.05-0.1 \mathrm{~m}$ & $0.1-0.2 \mathrm{~m}$ \\
\hline O $139 \mathrm{WG}$ & $5.77 b$ & $5.92 b$ & $6.10 \mathrm{ab}$ & $0.32 b$ & $0.37 \mathrm{ab}$ & $0.35 b$ \\
\hline EO WG & $5.74 b$ & $6.54 \mathrm{ab}$ & $6.79 a$ & $0.31 b$ & $0.38 \mathrm{ab}$ & $0.38 \mathrm{ab}$ \\
\hline O $61 \mathrm{WG}$ & $6.35 b$ & $6.74 \mathrm{ab}$ & $6.99 a$ & $0.37 \mathrm{ab}$ & $0.39 \mathrm{ab}$ & $0.42 \mathrm{ab}$ \\
\hline T WG & $6.51 b$ & $6.82 \mathrm{ab}$ & $6.27 \mathrm{ab}$ & $0.33 b$ & $0.38 \mathrm{ab}$ & $0.38 \mathrm{ab}$ \\
\hline CON WG & $6.24 b$ & $6.15 \mathrm{ab}$ & $6.32 \mathrm{ab}$ & $0.34 b$ & $0.39 \mathrm{ab}$ & $0.35 b$ \\
\hline O $1391 \mathrm{G}$ & $6.20 \mathrm{~b}$ & $6.59 \mathrm{ab}$ & $6.01 \mathrm{ab}$ & $0.40 \mathrm{ab}$ & $0.41 \mathrm{ab}$ & $0.38 \mathrm{ab}$ \\
\hline EO $1 \mathrm{G}$ & $6.69 b$ & $6.72 \mathrm{ab}$ & $6.13 \mathrm{ab}$ & $0.49 \mathrm{ab}$ & $0.49 \mathrm{ab}$ & $0.43 \mathrm{ab}$ \\
\hline $\mathrm{O} 611 \mathrm{G}$ & $7.09 \mathrm{~b}$ & $6.32 \mathrm{ab}$ & $6.53 \mathrm{a}$ & $0.44 \mathrm{ab}$ & $0.40 \mathrm{ab}$ & $0.49 \mathrm{ab}$ \\
\hline $\mathrm{T} 1 \mathrm{G}$ & $6.29 b$ & $7.15 \mathrm{a}$ & $6.91 \mathrm{a}$ & $0.41 \mathrm{ab}$ & $0.43 \mathrm{ab}$ & $0.42 \mathrm{ab}$ \\
\hline CON $1 \mathrm{G}$ & $6.67 b$ & $6.28 \mathrm{ab}$ & $6.21 \mathrm{ab}$ & $0.46 a b$ & $0.44 \mathrm{ab}$ & $0.43 \mathrm{ab}$ \\
\hline O $1392 \mathrm{G}$ & $6.88 b$ & $6.65 \mathrm{ab}$ & $6.27 \mathrm{ab}$ & $0.45 \mathrm{ab}$ & $0.44 \mathrm{ab}$ & $0.42 \mathrm{ab}$ \\
\hline EO $2 \mathrm{G}$ & $6.04 \mathrm{~b}$ & $6.07 b$ & $6.32 \mathrm{ab}$ & $0.44 \mathrm{ab}$ & $0.42 \mathrm{ab}$ & $0.46 \mathrm{ab}$ \\
\hline $\mathrm{O} 612 \mathrm{P}$ & $6.60 \mathrm{~b}$ & $6.92 \mathrm{ab}$ & $7.00 \mathrm{a}$ & $0.38 \mathrm{ab}$ & $0,40 \mathrm{ab}$ & $0.40 \mathrm{ab}$ \\
\hline $\mathrm{T} 2 \mathrm{G}$ & $6.74 b$ & $6.83 \mathrm{ab}$ & $6.38 \mathrm{ab}$ & $0.47 \mathrm{ab}$ & $0.46 \mathrm{ab}$ & $0.46 \mathrm{ab}$ \\
\hline $\mathrm{CON} 2 \mathrm{G}$ & $6.86 \mathrm{~b}$ & $7.05 \mathrm{a}$ & $6.17 \mathrm{ab}$ & $0.46 \mathrm{ab}$ & $0.47 \mathrm{ab}$ & $0.43 \mathrm{ab}$ \\
\hline Forest & $8.92 \mathrm{a}$ & $7.47 \mathrm{a}$ & $6.79 a$ & $0.47 \mathrm{a}$ & $0.42 \mathrm{a}$ & $0.49 a$ \\
\hline Haymaking & $6.40 \mathrm{~b}$ & $5.72 b$ & $5.10 \mathrm{~b}$ & $0.39 \mathrm{~b}$ & $0.42 \mathrm{~b}$ & $0.44 \mathrm{~b}$ \\
\hline
\end{tabular}

Note. Means followed by the same lowercase letter in the column do not differ statistically by the Dunnett test (5\%), from controls, means without letter are diffrent from controls. O 139: Oat 139; EO: Emeralda Oat; O 61: Oat 61; T: Triticale; CON: Consortium; WG: Without Grazing; 1G: 1 Grazing: 2G: 2 Grazing.

The values of the AE/HUM ratio, in this work, were equal and intermediate the reference areas for all the managements, ranging from 0.31 to 0.49 (Table 6). The quotient between AE/HUM indicates the illuviation of organic matter or organic carbon in the soil, and for Martins, Coringa and Weber (2009), evaluating different management systems, the systems presented the following order: pasture $>$ forest $>$ agroforest $>$ silvopastoril. For Campos et al. (2013), evaluating different 
management systems in a Yellow Latosol, the highest values of the relation AE/HUM were found for the no-tillage with five years of adoption.

The low values of the AE/HUM ratio in this work are also due to the high levels of HUM found in the evaluated areas, mainly due to the high clay content, a pattern also observed by Rosset et al. (2016). Fontana et al. (2010), found values of the $\mathrm{AE} / \mathrm{HUM}$ ratio varying between 0.27 and 1.03 , which are considered to be low, as they are indicative of the insolubility of the organic matter and high stability between this and the mineral matrix of the soils.

\section{CONCLUSIONS}

The native Forest area presented the best values for most of the fractions studied.

Conservation systems such as ICLS can match the soil quality of the reference system, but they require an adequate management system and time.
The POC fraction was more sensitive than TOC to detect variations in a short period of time.

The use of grasses tends to promote carbon increment in depth.

The main alterations of $\mathrm{C}$ in the soil are due to the inadequate management system of the area before the beginning of the conversion to the ICLS.

\section{ACKNOWLEDGEMENTS}

This study was financed in part by the Coordenação de Aperfeiçoamento de Pessoal de Nível Superior - Brasil (CAPES) - Finance Code 001. We want to give thanks to the Coordination for the Improvement of Higher Education Personnel (CAPES) by the scholarship and resources for conducting the research and the National Council for Scientific and to Technological Development (CNPq) for the productivity scholarship granted to the researcher Dr. Paulo Sérgio Rabello Oliveira.

RESUMO: O objetivo desse trabalho foi avaliar os teores de carbono das frações física, química e oxidável da matéria orgânica do solo (MOS) e calcular o índice de manejo de carbono (IMC) em uma área manejada em sistema de integração lavoura pecuária (ILP) na região Oeste do Paraná - Brasil. O experimento foi realizado na fazenda experimental, pertencente à Universidade Estadual do Oeste do Paraná. Foram avaliadas dezessete áreas, que foram manejadas de diferentes formas, quinze em ILP e duas testemunhas (Mata e Fenação), sendo empregado o delineamento subsubsubdividido com duas testemunhas aninhadas, com três repetições. Em todas as áreas foram coletadas amostras deformadas e indeformadas de solo para serem determinados o carbono orgânico total, estoque de carbono e as frações físicas granulométricas, oxidáveis e químicas da MOS e o IMC nas camadas de 0-0,05, 0,05-0,1 e 0,1-0,2 m. Alterações pouco significativas das frações foram encontradas para os manejos da área em ILP em relação a mata e a área de fenação, entretanto a mata apresentou os melhores valores para a maioria das frações estudadas. Recomenda-se a adoção de práticas sustentáveis, como a ILP, mesmo que os teores médios das frações tendem a demorar tempo para igualar-se a áreas de referência.

PALAVRAS CHAVES: Estoque de carbono. Substâncias húmicas. Carbono particulado.

\section{REFERENCES}

ALVARES, C. A.; STAPE, J. L.; SENTELHAS, P. C.; GONÇALVES, J. L. de M.; SPAROVEK, G. Köppen's climate classification map for Brazil. Meteorologische Zeitschrift, v.22, n.6, p.711-728, 2014. https://doi.org/10.1127/0941-2948/2013/0507

BAldotTO, M. A.; GOBO, A. A. R.; SAlOMÃO, M. S. M. B.; REZENDE, C. E.; CAMARGO, P. B. Fractions of organic matter and redox properties of humic substances in sediments from deep oceans. Química Nova, v.36, n.9, p.1288-1295, 2013. https://doi.org/10.1590/S0100-40422013000900003

BALDOTTO, M. A.; VIEIRA, E. M.; SOUZA, D. O.; BALDOTTO, L. E. B. Organic carbon stocks and fractions and soil fertility under forest, agriculture and livestock. Revista Ceres, v.62, n.3, p.301-309, 2015. https://doi.org/10.1590/0034-737X201562030010 
BALIN. N. M.; ZIECH, A. R. D.; OLIVEIRA, J. P. M.; GIRARDELLO, V. C.; STUMPF, L.; CONCEIÇÃO, P. C. Fractions of organic matter, carbon management index and physical attributes of a red oxisol under different use systems. Revista Scientia Agraria, v.18, n.3, p.85-94, 2017.

https://doi.org/10.5380/rsa.v18i3.53114

BARRETO, P. A. B.; GAMA-RODRIGUES, E. F.; GAMA-RODRIGUES, A. C.; FONTES, A. G.; POLIDORO, J. C.; MOÇO, M. K. S.; MACHADO, R. C. R.; BALIGAR, V. C. Distribution of oxidizable organic $\mathrm{C}$ fractions in soils under cacao agroforestry systems in Southern Bahia, Brazil. Agroforestry Systems, v.81, n.3, p.213-220, 2011. https://doi.org/10.1007/s10457-010-9300-4

BATISTA, I.; PEREIRA, M. G.; CORREIA, M. E. F.; BIELUCZYK, W.; SCHIAVO, J. A.; ROWS, J. R. C. Content and carbon stocks in labile and recalcitrant organic matter of the soil under crop-livestock integration in Cerrado. Semina: Ciências Agrárias, v.34, n.6, p.3377-3388, 2013. https://doi.org/10.5433/16790359.2013v34n6Supl1p3377

BAYER, C.; AMADO, T. J. C.; TORNQUIST, C. G.; CERRI, C. E. P.; DIECKOW, J.; ZANATTA, J. A.; NICOLOSO, R.S. Estabilização do carbono no solo e mitigação das emissões de gases de efeito estufa na agricultura conservacionista. In: KLAUBERG FILHO, O.; MAFRA, A.L.; GATIBONI, L.C., eds. Tópicos em ciência do solo. Viçosa, MG, 2011. v.7. p.55-118.

BENITES, V. M.; MADARI, B.; MACHADO, P. L. O. A. Extração e fracionamento quantitativo de substâncias húmicas do solo: um procedimento simplificado e de baixo custo. Rio de Janeiro, Embrapa Solos, 2003. 7p. (Comunicado Técnico, 16).

BENITES, V. M.; MOUTTA, R. O.; COUTINHO, H. L. C.; BALIEIRO, F. C. Discriminant analysis of soils under different land uses in the Atlantic Rain Forest area using organic matter attributes. Revista Árvore, v.34, n.4, p.685-690, 2010. https://doi.org/10.1590/S0100-67622010000400013

BLAIR, G. J.; LEFROY, R. D. B.; LISLE, L. Soil carbón fractions, base don their degree of oxidations, and the development of carbón management index for agricultural systems. Australian Journal of Agricultura Research, v.46, n.7, p.1459-1466, 1995. https://doi.org/10.1071/AR9951459

CAMBARDELLA, C. A.; ELLIOT, E. T. Particulate soil organic-matter changes across a grassland cultivation sequence. Soil Science Society of America Journal, v.56, n.3, p.777-783, 1992.

https://doi.org/10.2136/sssaj1992.03615995005600030017x

CAMPOS, L. P.; LEITE, L. F. C.; MACIEL, G. A.; BRASIL, E. L.; IWATA, B. de F. Stocks and fractions of organic carbon in an Oxisol under different management systems. Pesquisa Agropecuária Brasileira, v.48, n.3, p.304-312, 2013. https://doi.org/10.1590/S0100-204X2013000300009

CANELlAS, L. P.; VELlOSO, A. C. X.; MARCIANO, C. R.; RAMALHO, J. F. G. P.; RUMJANEK, V. M.; REZENDE, C. E.; SANTOS, G.A. Chemical soil properties of an inceptisol under long-term sugarcane crops with vinasse application and without slash burning. Revista Brasileira de Ciência do Solo, v.27, n.5, p.935944, 2003. https://doi.org/10.1590/S0100-06832003000500018

CANELLAS, L. P.; SANTOS, G. de A. Humusfera: tratado preliminar sobre a química das substâncias húmicas. Campos dos Goytacazes: UENF, 2005. 310p.

CARMO, F. F.; FIGUEIREDO, C. C.; RAMOS, M. L. G.; VIVALDI, L. J.; ARAÚJO, L. G. Granulometric fractions of organic matter of a latosol under no-till with grasses. Bioscience Journal, v.28, n.3, p.420-431, 2012.

CARVAlHO, J. L. N.; CERRI, C. E. P.; FEIGL, B. J.; PÍCOLlO, M. C.; GODINHO, V. P.; CERRI, C. C. Carbon sequestration in a agricultural soils in the Cerrado of the Brazilian Amazon. Soil \& Tillage Research, v.103, n.2, p.342-349, 2009. https://doi.org/10.1016/j.still.2008.10.022 
CASTAGNARA, D. D.; OLIVERA, P. S. O.; BULEGON, L. G.; NERES, M. A.; PIANO, J. T.; ZOZ, T.; GERHARDT, I. F. S. Physical properties of Rhodic Hapludox (Oxisol) soil under different oat managements of integrated crop-livestock system. Australian Journal of Crop Science, v.9, n.8, p.734-743, 2015.

CERRI, C.; VOLKOFF, B. Organic matter of three soils from the flooded fields of the marajo island (state of Pará, Brazil). Revista Brasileira de Ciência do Solo, v.12, p.93-100, 1988.

CHAN, K. Y.; BOWMAN, A.; OATES, A. Oxidizible organic carbon fractions and soil quality changes in an Paleustalf under different pasture leys. Soil Science, v.166, n.1, p.61-67, 2001.

https://doi.org/10.1097/00010694-200101000-00009

CONCEIÇÃO, P. C.; BAYER, C.; DIECKOW, J.; SANTOS, D. C. Physical fractionation of organic matter and carbon management index of an Alfisol subjected to conservation management systems. Ciência Rural, v.44, n.5, p.794-800, 2014. https://doi.org/10.1590/S0103-84782014005000004

CONTE, O.; WESP, C. de L.; ANGHINONI, I.; CARVALHO, P. C. de F.; LEVIEN, R.; NABINGER, C. Soil density, aggregation and carbon fractions of an Alfisol under natural pasture and different herbage allowance. Revista Brasileira de Ciência do Solo, v.35, n.2, p.579-587, 2011. https://doi.org/10.1590/S010006832011000200027

CRUZ, C. D. Genes: A Software Package for Analysis in Experimental Statistics and Quantitative Genetics. Acta Scientiarum Agronomy, v.35, n.3, p.271-276, 2013. https://doi.org/10.4025/actasciagron.v35i3.21251

DONAGEMA, G. K.; CAMPOS, D. V. B.; CALDERANO, S. B.; TEIXEIRA, W. G.; VIANA, J. H. M. Manual de métodos de análises de solo. 2.ed. (Revista), Rio de Janeiro, Embrapa Solos, 2011. 230p.

DORTZBACH, D.; PEREIRA, M. G.; BLAINSKI, E.; GONZÁLEZ, A. P. Carbon Stock and Natural Abundance of ${ }^{13} \mathrm{C}$ as a Function of Conversion of Forest and Grassland Areas in Southern Brazil. Revista Brasileira de Solo, v.39, n.6, p.1643-1660, 2015. https://doi.org/10.1590/01000683rbcs20140531

ELLERT, B. H.; BETTANY, J. R. Calculation of organic matter and nutrients stored in soils under contrasting management regimes. Canadian Journal of Soil Science, v.75, n.4, p.529-538, 1995.

https://doi.org/10.4141/cjss95-075

FACCIN, F. C.; MARCHETTI, M. E.; SERRA, A. P.; ENSINAS, S. C. Granulometric fractions of soil organic matter in intercropping of off-season corn with Marandu grass under nitrogen sources. Pesquisa Agropecuária Brasileira, v.51, n.12, p.2000-2009, 2016. https://doi.org/10.1590/s0100-204x2016001200011

FONTANA, A.; PEREIRA, M. G.; ANJOS, L. H. C.; BENITES, V. M. Humic fractions quantification as a differential characteristic and use in diagnostic horizons in Brazilian soils. Revista Brasileira de Ciência do Solo, v.34, n.5, p.1241-1257, 2010. https://doi.org/10.1590/S0100-06832010000400023

FONTANELI, R. S; SANTOS, H. P. dos; FONTANELLI, R. S. Forrageiras para Integração LavouraPecuária-Floresta na Região Sul-Brasileira. 2. ed. Brasília, DF: Embrapa Trigo, 2012. 544 p.

FREIXO, A. A.; MACHADO, P. L. O. A.; GUIMARÂES, C. M.; SILVA, C. A.; FADIGAS, F. S. Carbon and nitrogen storage and organic fraction distribution of a cerrado oxisol under diferent cultivation systems.

Revista Brasileira de Ciência do Solo, v.26, n.1, p.425-434, 2002. https://doi.org/10.1590/S010006832002000200016

GATTO, A.; BARROS, N. F. de; NOVAIS, R. F.; SILVA, I. R.; LEITE, H. G.; LEITE, F. P.; VILLANI, E. M. A. Carbon storage in the soil and in the biomass of eucalypt plantations. Revista Brasileira de Ciência do Solo, v.34, n.4, p.1069-1080, 2010. https://doi.org/10.1590/S0100-06832010000400007 
GAZOLLA, P. R.; GUARESCHI, R. F.; PERIN, A.; PEREIRA, M. G.; ROSSI, C. Q. Fractions of soil organic matter under pasture, tillage system and crop-livestock integration. Semina: Ciências Agrárias, v.36, n.2, p.693-704, 2015.

HICKMANN, C.; COSTA, L. M. Carbon stock in soil and aggregates in Ultisol under different management of long duration. Revista Brasileira de Engenharia Agrícola e Ambiental, v.16, n.10, p.1055-1061, 2012. https://doi.org/10.1590/S1415-43662012001000004

KUNDE, R. J.; LIMA, C. L. R.; SILVA, S. D. A.; PILLON, C. N. Physical fractions of organic matter in an Oxisol cultivated with sugarcane in the state of Rio Grande do Sul, Brazil. Pesquisa Agropecuária Brasileira, v.51, n.9, p.1520-1528, 2016.

LEAL, O. A.; CASTILHOS, R. M. V.; PAULETTO, E. A.; PINTO, L. F. S.; PILLON, C. N.; PENNING, L. H.; SANTOS, D. C. Organic Matter Fractions and Quality of the Surface Layer of a Constructed and Vegetated Soil after Coal Mining. II - Physical Compartments and Carbon Management Index. Revista Brasileira de Ciência do Solo, v.39, n.6, p.895-902, 2015. https://doi.org/10.1590/01000683rbcs20140784

LEITE, L. F. C. ARRUDA, F. P.; COSTA, C. N.; FERREIRA, J. S.; HOLANDA NETO, M. R. Chemical quality of soil and dynamics of carbon under monoculture and intercroping of acrocomia palm and pasture. Revista Brasileira de Engenharia Agrícola e Ambiental, v.17, n.12, p.1257-1263, 2013. https://doi.org/10.1590/S1415-43662013001200002

LOSS, A.; PEREIRA, M. G.; SCHULTZ, N.; ANJOS, L. H. C.; SILVA, E. M. R. Carbon and granulometry fractions of soil organic matter under organic production system. Ciência Rural, v.39, n.4, p.1077-1082, 2009.

LOSS, A.; PEREIRA, M. G.; SCHULTZ, N.; ANJOS, L. H. C.; SILVA, E. M. R. Carbon quantification of humic substances in different soil use systems and evaluation periods. Bragantia, v.69, n.4, p.913-922, 2010. https://doi.org/10.1590/S0006-87052010000400018

LOSS, A.; PEREIRA, M. G.; COSTA, E. M.; BEUTLER, S. J. Granulometric and oxidizable fractions of organic matter under different land use systems in the state of Paraná, Brazil. Bioscience Journal, v.30, n.1, p.43-54, 2014.

MARTINS, E. de L.; CORINGA, J. do E. S.; WEBER, O. L. dos S. Organic carbon in granulometric fraction and in humic substances of a Brazilian Oxisol under different land use systems. Acta Amazonica, v.39, n.3, p.655-660, 2009. https://doi.org/10.1590/S0044-59672009000300021

MARTINS, C. M.; COSTA, L. M. da; SCHAEFER, C. E. G.R.; SOARES, E. M. B.; SANTOS, S. R. dos. Fraction of organic matter in soil under deciduous formations in the north of minas. Revista Caatinga, v.28, n.4, p.10-20, 2015. https://doi.org/10.1590/1983-21252015v28n402rc

MELO, G. B.; PEREIRA, M. G.; PERIN, A.; GUARESCHI, R. F.; SOARES, P. F. C. Storage and fractions of soil organic matter under no-tillage and conventional planting systems of cabbage. Pesquisa Agropecuária Brasileira, v.51, n.9, p.1511-1519, 2016. https://doi.org/10.1590/s0100-204x2016000900050

MENDONÇA, E. de S.; MATOS, E. da S. (ed.). Matéria orgânica do solo: métodos de análises. 2. ed. rev. atual. Viçosa, MG: UFV, Gefert, 2017. 221 p.

PARTELLI, F. L.; BUSATO, J. G.; VIEIRA, H. D.; VIANA, A. P.; CANELLAS, L. P. Organic matter quality and phosphorus distribution in soils under organic Conilon coffee. Ciência Rural, v.39, n.7, p.2065-2072, 2009. https://doi.org/10.1590/S0103-84782009000700017

PEREIRA, M. F. S.; NOVO JÚNIOR, J.; SÁ, J. R.; LINHARES, P. C. F.; BEZERRA NETO, F.; PINTO, J. R. S. Ciclagem do carbono do solo nos sistemas de plantio direto e convencional. Agropecuária Científica no Semiárido, v.9, n.2, p.21-32, 2013. 
PIANO, J. T.; OLIVEIRA, P. S. R. de; COSTA, P. F. da; TAFFAREL, L. E.; EGEWARTH, J. F.; SEIDEL, E. P.; CASTAGNARA, D. D.; BORSOI, A.; EGEWARTH, V. A. Soil physical attributes under different grazing management of winter forage crops in crop-livestock system at Southern Brazil. African Journal of Agricultural Research, v.10, n.3, p.146-153, 2015. https://doi.org/10.5897/AJAR2014.8943

PORTUGAL, A. F.; JUCKSCH, I.; SCHAEFER, C. G. R.; WENDLING, B. Determination of total organic carbon and nitrogen stocks and their fractions in and ultisol under different land uses. Revista Brasileira de Ciência do Solo, v.32, n.5, p.2091-2100, 2008. https://doi.org/10.1590/S0100-06832008000500030

PULROLNIK, K.; BARROS, N. F. de; SILVA, I. R; NOVAIS, R. F.; BRANDANI, C. B. Carbon and nitrogen pools in soil organic matter under eucalypt, pasture and savanna vegetation in Brazil. Revista Brasileira de Ciência do Solo, v.33, n.5, p.1125-1136, 2009. https://doi.org/10.1590/S0100-06832009000500006

R Development Core Team. R: A Language and Environment for Statistical Computing. Vienna, Áustria: The R Foundation for Statistical Computing. 2016.

REIS, D. A., LIMA, C. L. R.; BAMBERG, A. L. Physical quality and organic matter fractions of an Alfisol under no-tillage. Pesquisa Agropecuária Brasileira, v.51, n.9, p.1623-1632, 2016.

https://doi.org/10.1590/s0100-204x2016000900062

ROSSET, J. S.; LANA, M. do C.; PEREIRA, M. G.; SCHIAVO, J. A.; RAMPIM, L.; SARTO, M. V. M. Chemical and oxidizable fractions of soil organic matter under different management systems in an Oxisol. Pesquisa Agropecuária Brasileira, v.51, n.9, p.1529-1538, 2016. https://doi.org/10.1590/s0100204x2016000900052

ROSSI, C. Q.; PEREIRA, M. G.; GIACOMO, S. G.; BETTA, M.; POLIDORO, J. C. Humic fractions of organic matter in soil cultivated with soybean on straw of brachiaria and sorghum. Bragantia, v.70, n.3, p.622630, 2011. https://doi.org/10.1590/s0100-204x2016000900052

ROSSI, C. Q.; PEREIRA, M. G.; GIÁCOMO, S. G.; BETTA, M.; POLIDORO, J. C. Organic fractions and soil organic carbon management index in an Oxisol under soybean cultivation in the cerrado region of Goiás, Brazil. Revista Brasileira de Ciências Agrárias, v.7, n.2, p.233-241, 2012. https://doi.org/10.5039/agraria.v7i2a1387

ROZANE, D. E.; CENTURION, J. F.; ROMUALDO, L. M.; TANIGUCHI, C. A. K.; TRABUCO, M. ALVES, A. U. Carbon supply and stability of haplustox aggregates under different managements. Bioscience Journal, v.26, n.1, p.24-32, 2010. https://doi.org/10.5433/1679-0359.2011v32n1p111

SALTON, J. C.; BAYER, C.; FABRÍCIO, A. C.; MACEDO, M. C. M.; BROCH, D. L. Contents and dynamics of soil carbon in integrated crop-livestock systems. Pesquisa Agropecuária Brasileira, v.46, n.10, p.13491356, 2011. https://doi.org/10.1590/S0100-204X2011001000031

SANTOS, H. G. dos; JACOMINE, P. K. T.; ANJOS, L. H. C. dos; OLIVEIRA, V. A. de; LUMBRERAS, J. F.; COELHO, M. R.; ALMEIDA, J. A. de; CUNHA, T. J. F.; OLIVEIRA, J. B. de. Sistema Brasileiro de Classificação de Solos. 3.ed. Rio de Janeiro, RJ: Embrapa Solos, 2013a. 353p.

SANTOS, D. C.; FARIAS, M. O.; LIMA, C. L. R.; KUNDE, R. J.; PILLON, C. N.; FLORES, C. A. Physical and chemical fractionation of organic matter of an Alfisol under different use systems. Ciência Rural, v.43, n.5, p.838-844, 2013b. https://doi.org/10.1590/S0103-84782013005000037

SCHIAVO, J. A.; ROSSET, J. S.; PEREIRA, M. G.; SALTON, J. C. Carbon management index and chemical attributes of an Oxisol under different management systems. Pesquisa Agropecuária Brasileira, v.46, n.10, p.1332-1338, 2011. https://doi.org/10.1590/S0103-84782013005000037 
SIGNOR, D.; ZANI, C. F.; PALADINI, A. A.; DEON, M. D.; CERRI, C. E. P. Carbon stocks and quality of soil organic matter in sugarcane fields. Revista Brasileira de Ciência do Solo, v.38, n.5, p.1402-1410, 2014. https://doi.org/10.1590/S0100-06832014000500005

SILVA, E. F.; LOURENTE, E. P. R.; MARCHETTI, M. E.; MERCANTE, F. M.; FERREIRA, A. K.T.; FUJII, G. C. Labile and recalcitrant fractions of soil organic matter under integrated crop-livestock system. Pesquisa Agropecuária Brasileira, v.46, n.10, p.1321-1331, 2011. https://doi.org/10.1590/S0100-204X2011001000028

SILVA, C. F.; PEREIRA, M. G.; MIGUEL, D. L.; FEITORE, J. C. F.; LOSS, A. MENEZES, E. G.; SILVA, E. M. R. Total organic carbon, microbial biomass and soil enzyme activity areas of agriculture, forestry and grassland in the middle Valley of Paraíba do Sul River (RJ). Revista Brasileira de Ciência do Solo, v.36, n.6, p.1680-1689, 2012. https://doi.org/10.1590/S0100-06832012000600002

SILVA, V. E.; SILVA, A. C.; PEREIRA, R. C.; CAMARGO, P. B.; SILVA, B. P. C.; BARRAL, U. M.; MENDONÇA FILHO, C. V. Lignocellulosic and isotopic composition of vegetation and soil organic matter of a tropical peat. I floristic composition, biomass and carbon stock. Revista Brasileira de Ciência do Solo, v.37, n.1, p.121-133, 2013. https://doi.org/10.1590/S0100-06832013000100013

SOUZA, E. D.; COSTA, S. E. V. G. A.; CARVALHO, P. C. F.; ANDRIGUETI, M.; CAO, E. Soil organic carbon and nitrogen stocks in an untilled crop-livestock integration system under different grazing intensities. Revista Brasileira de Ciência do Solo, v.33, n.6, p.1829-1836, 2009. https://doi.org/10.1590/S010006832009000600031

SOUZA, R. F. de; FIGUEIREDO, C. C. de; MADEIRA, N. R.; ALCÂNTARA, F. A. de. Effect of management systems and cover crops on organic matter dynamics of soil under vegetables. Revista Brasileira de Ciência do Solo, v.38, n.3, p.923-933, 2014. https://doi.org/10.1590/S0100-06832014000300024

SWIFT, R. S. Organic matter characterization. In: SPARKS, D. L.; PAGE, A. L.; HELMKE, P. A.; LOEPPERT, R. H.; SOLTANPOUR, P. N.; TABATABAI, M. A.; JOHNSTON, C. T.; SUMNER, M. E. (eds) Methods of soil analysis: chemical methods. Madison: Soil Science Society American, v.3, p.1011-1020, 1996.

VELOSO, H. P.; RANGEL FILHO, A. L. R.; LIMA, J. C. A. Classificação da vegetação brasileira adaptada a um sistema internacional. Rio de Janeiro: IBGE, 1991. 124p.

YEOMANS, J. C.; BREMNER, J. M. A rapid and precise method for routine determination of carbon in soil. Communications in Soil Science and Plant Analysis, v.19, n.13, p.1467-1476, 1988.

https://doi.org/10.1080/00103628809368027 